\title{
Tetrodotoxin-sensitive $\mathrm{Ca}^{2+}$ currents, but no T-type currents in normal, hypertrophied and failing mouse cardiomyocytes
}

\author{
Ilona Bodi, PhD, Hiroyuki Nakayama, MD, PhD, and Arnold Schwartz, PhD* \\ Department of Pediatrics, Division of Molecular Cardiovascular Biology, Cincinnati Children's \\ Hospital Medical Center, Cincinnati, Ohio \\ *Department of Internal Medicine, Division of Cardiovascular Health and Disease, University of \\ Cincinnati Medical Center, Cincinnati, Ohio
}

\begin{abstract}
Aims-To obtain functional evidence that $\mathrm{I}_{\mathrm{Ca}, \mathrm{T}}$ is involved in the pathogenesis of cardiac hypertrophy and heart failure. We unexpectedly identified $\mathrm{I}_{\mathrm{Ca}(\mathrm{TTX})}$ rather than $\mathrm{I}_{\mathrm{Ca}, \mathrm{T}}$, therefore, we adjusted our aim to encompass these findings.
\end{abstract}

Methods and Results-We investigated 1) $\mathrm{Ca}_{\mathrm{v}} 3.1\left(\mathrm{a}_{1 \mathrm{G}}\right)$ transgenic $(\mathrm{Tg})$ mice compared with non-transgenic (tTA-Ntg) 2) $\mathrm{Ca}_{\mathrm{v}} 3.1$ deficient mice $\left(\mathrm{Ca}_{\mathrm{v}} 3.1^{-/-}\right)$compared with wild-type (Wt) after chemically and surgically induced cardiac remodeling 3) Spontaneous hypertensive rats (SHR) and thoracic aortic constriction (TAC) rats.

Whole cell patch clamp technique was used to measure $\mathrm{I}_{\mathrm{Ca}}$ in ventricular myocytes (VMs). $\mathrm{Ca}_{\mathrm{v}} 3.1-\mathrm{Tg}$ expressed $\mathrm{I}_{\mathrm{Ca}, \mathrm{T}}(-18.35 \pm 1.02 \mathrm{pA} / \mathrm{pF}$ at $-40 \mathrm{mV})$ without signs of compromised cardiac function. While we failed to detect $\mathrm{I}_{\mathrm{Ca}, \mathrm{T}}$ after hypertrophic stimuli, instead we demonstrated that both Wt and $\mathrm{Ca}_{\mathrm{v}} 3 \cdot 1^{-/-}$mouse exhibit $\mathrm{I}_{\mathrm{Ca}(\mathrm{TTX})}$. Using TAC rats, only 2 of $24 \mathrm{VMs}$ showed $\mathrm{I}_{\mathrm{Ca}, \mathrm{T}}$ under our experimental conditions. Without TTX, $\mathrm{I}_{\mathrm{Ca}(\mathrm{TTX})}$ occurred in VMs from Wt, SHR and TAC rats also.

Conclusions-These findings demonstrate for the first time that mouse VMs express $\mathrm{I}_{\mathrm{Ca}(\mathrm{TTX}) \text {. }}$ We suggest that future studies should take into consideration the measuring conditions when interpreting $\mathrm{I}_{\mathrm{Ca}, \mathrm{T}}$ reappearance in ventricular myocytes in response to hypertrophic stress. Contamination with $\mathrm{I}_{\mathrm{Ca}(\mathrm{TTX})}$ could possibly confuse the relevance of the data.

\section{Keywords}

$\mathrm{Ca}^{2+}$ channel; cardiac hypertrophy; tetrodotoxin-sensitive $\mathrm{Ca}^{2+}$ currents; T-type $\mathrm{Ca}^{2+}$-channel; patch clamp; mouse cardiomyocytes

Corresponding Author: Dr. Arnold Schwartz, Department of Internal Medicine, University of Cincinnati Medical Center, G936 Cardiovascular Research Center, 231 Albert Sabin Way, Cincinnati, OH 45267-0828, Phone: 513-509 6262, Fax: 513-558-1778, schwara@ucmail.uc.edu.

The conflict of interest disclosure statement: none declared. 


\section{INTRODUCTION}

Low voltage activated $\mathrm{Ca}^{2+}$ channels (LVACC), referred to as T-type $\mathrm{Ca}^{2+}$ channels $\left(\mathrm{I}_{\mathrm{Ca}, \mathrm{T}}\right)$ are expressed in heart, kidneys, smooth muscle, sperm, neurons and endocrine organs. Three T-type $\mathrm{Ca}^{2+}$ channel pore-forming subunits are encoded by the $\mathrm{Ca}_{\mathrm{v}} 3$ genes $\left(\mathrm{Ca}_{\mathrm{v}} 3.1 / \mathrm{a}_{1 \mathrm{G}}\right.$, $\mathrm{Ca}_{\mathrm{v}} 3.2 / \mathrm{a}_{1 \mathrm{H}}$ and $\mathrm{Ca}_{\mathrm{v}} 3.3 / \mathrm{a}_{1 \mathrm{I}}$, two are expressed in the heart. ${ }^{1}$ Some propose that the major functional role of this $\mathrm{Ca}^{2+}$ channel in myocardial tissue is related to cell proliferation ${ }^{2}$ and pacemaker activity. ${ }^{3}$ It is well documented that $\mathrm{I}_{\mathrm{Ca}, \mathrm{T}}$ is abundantly expressed in embryonic and neonatal ventricular myocytes (VMs), but is undetectable in adult VMs. Several studies have reported that cardiac $\mathrm{I}_{\mathrm{Ca}, \mathrm{T}}$ may "reappear" in some phases of pathological cardiac remodeling in some animal models. ${ }^{4-9}$ To reinforce this concept, the beneficial effects of Ttype channel blockers (mibefradil, efonidipine, ethosuximide) on cardiac remodeling were supported in some ${ }^{8,10-12}$ but not all pharmacological models. ${ }^{13,14}$ Many of the contradictory findings concerning the usage of T-type channel inhibitors in pharmacological models can be attributed to their imperfect selectivity and indirect effects.

As is often the case, despite considerable efforts, the contribution of $\mathrm{I}_{\mathrm{Ca}, \mathrm{T}}$ to the alterations in cytosolic $\left[\mathrm{Ca}^{2+}\right]_{\mathrm{i}}$ in pathological hypertrophy (HT) and heart failure (HF) and, as well as their possible protective effects remains speculative and controversial. ${ }^{10,14-16}$

The present study was designed to test the hypothesis that pathological cardiac HT is associated with electrical remodeling inducing the functional re-expression of $\mathrm{I}_{\mathrm{Ca}, \mathrm{T}}$. To confirm the generality of this hypothesis patch clamp experiments were carried out to study the functional expression of $\mathrm{I}_{\mathrm{Ca}, \mathrm{T}}$ using different approaches: Firstly, two mouse models of mechanically-induced left ventricular hypertrophy (produced by Thoracic Aortic Constriction (TAC) resulting in a pressure overload) and chemically-induced cardiac hypertrophy (produced by chronic infusion of the $\beta$-agonist isoproterenol (Iso) via miniosmotic pumps) in Wild type (Wt) and in a genetic model lacking the gene coding for the cardiac T-type calcium channel subunit $\mathrm{Ca}_{\mathrm{v}} 3 \cdot 1\left(\mathrm{Ca}_{\mathrm{v}} 3 \cdot 1^{-/-}\right.$mice $)$. We chose the latter because previous studies implicated $\mathrm{Ca}_{\mathrm{v}} 3.2$ channel involvement in the development of ventricular HT. ${ }^{10,17}$ Secondly, three additional mouse models were examined, viz.: the $\mathrm{Ca}_{\mathrm{v}} 1.2 \mathrm{a}_{1 \mathrm{C}}{ }^{18}$ the calcineurin ${ }^{19}$ and the mutant a-tropomyosin (a-TM5Glu54Lys) ${ }^{20}$ over expressing Tg mice and two rat models (SHR and TAC rat), all of them leading to cardiac hypertrophy and failure. These approaches are especially interesting because of an impressive and provocative study has been reported on this subject by Chiang et al. ${ }^{10}$ The authors showed that electrophysiologically (EP) detectable $\mathrm{I}_{\mathrm{Ca}, \mathrm{T}}$ reappeared in left $\mathrm{VMs}$ after $\mathrm{Wt}$ and $\mathrm{Ca}_{\mathrm{v}} 3.2^{-/-}$mice were subjected to TAC for 2-weeks (wk), implying a causal relationship to cardiac hypertrophy. In our studies, using $\mathrm{Na}^{+}-\mathrm{K}^{+}$- free recording solution in the absence of tetrodotoxin (TTX) neither in Wt nor in $\mathrm{Ca}_{\mathrm{v}} 3.1^{-/-} \mathrm{VMs}$ derived from mice subjected to chronic Iso treatment ( $2 \mathrm{wk}$ ) or pressure overload $\left(5,11\right.$ days and 2 months) could a $\mathrm{Ni}^{2+}$ sensitive LVACC be observed. However, and surprisingly, a pronounced LVA TTX-sensitive inward current was detected. The lack of sensitivity of this inward current to $200 \mu \mathrm{mol} / \mathrm{L}$ $\mathrm{Ni}^{2+}$ proves that this current is not produced by $\mathrm{I}_{\mathrm{Ca}, \mathrm{T}}$. Indeed, this current exhibited kinetics and pharmacological characteristics of $\mathrm{I}_{\mathrm{Ca}}$ (TTX) previously described in detail by others. ${ }^{21,22}$ In this study, we provide evidence of the existence of $\mathrm{I}_{\mathrm{Ca}}$ (TTX) in ventricular myocytes isolated from both normal and hypertrophied mouse (and rat) hearts. 


\section{MATERIALS AND METHODS}

\section{Cardiomyocyte isolation from mice and rats}

Adult mice and rats of either sex were anaesthetized with combination of ketamine $(100 \mathrm{mg} / \mathrm{kg})$ - xylazine $(10 \mathrm{mg} / \mathrm{kg})(\mathrm{KX})$ and injected with $1.5 \mathrm{IU}$ of heparin intraperitoneally to prevent intracardiac blood coagulation. The heart was rapidly excised from the chest, mounted on a Langendorff apparatus and retrogradely perfused through the aorta at a constant flow rate $(3 \mathrm{ml} / \mathrm{min})$ for $5 \mathrm{~min}$ at $37^{\circ} \mathrm{C}$ with Tyrode solution (equilibrated with $95 \% \mathrm{O}_{2}-5 \% \mathrm{CO}_{2}$ ) containing (in mmol/L): $\mathrm{NaCl} 120, \mathrm{KCl} 5.4, \mathrm{NaH}_{2} \mathrm{PO}_{4} 1.2$, glucose 5.6, $\mathrm{NaHCO}_{3} 20, \mathrm{MgCl}_{2}$ 1, 2,3-butanedione monoxime (BDM) 10, and taurine 5. Perfusion was then switched to Tyrode solution containing $1 \mathrm{mg} / \mathrm{mL}$ collagenase Type II (Worthington). After $2 \mathrm{~min}$ of enzyme perfusion, $50 \mu \mathrm{mol} / \mathrm{L} \mathrm{Ca}^{2+}$ was added to the enzyme solution. When the heart became swollen and hard after $\sim 5 \mathrm{~min}$ of digestion, the enzyme was recirculated for an additional 8-12min or until flow rate surpassed pre-enzyme flow rate. After perfusion, the ventricles were separated from the atria, minced and gently agitated in low $\mathrm{Cl}^{-}$high $\mathrm{K}^{+}$ Kraft-Bruhe (KB) solution consisting of (in mmol/L): 1-glutamic-acid 50, $\mathrm{KCl} 40$, taurine 20, $\mathrm{KH}_{2} \mathrm{PO}_{4} 20, \mathrm{MgCl}_{2}$ 3, Glucose 10, EGTA 1, HEPES 10 (pH adjusted to 7.4 with $\mathrm{KOH}$ ). The dissociated cells were filtered through a nylon mesh, and stored at $4^{\circ} \mathrm{C}$ in $\mathrm{KB}$ solution until use. Only $\mathrm{Ca}^{2+}$ tolerant cells with clear cross striations and without spontaneous contractions or significant granulation were selected for the experiments. ${ }^{23}$

\section{Measurements of L-type and T-type calcium currents using patch clamp methods}

All current recordings were obtained in the whole-cell, voltage-clamp configuration of the patch clamp technique by using 1.60 OD borosilicate glass electrodes (Garner Glass Company) ${ }^{23}$ Cell capacitance was calculated by integrating the area under an uncompensated capacity transient elicited by a $25 \mathrm{mV}$ hyperpolarizing test pulse $(25 \mathrm{~ms})$ from a holding potential of $0 \mathrm{mV}$. Series resistance was within the range of 2 to $11 \mathrm{M} \Omega$. Most of the data presented in these studies were obtained with electrodes having a resistance of 0.5- $3 \mathrm{M} \Omega$. After formation of a high resistance seal between the recording electrode and the cell membrane, electrode capacitance was fully compensated electronically before breaking the membrane patch.

All patch clamp experiments were carried out at room temperature $\left(21-23^{\circ} \mathrm{C}\right)$ using a patch clamp amplifier (Axopatch 200A; Axon Instruments). The recorded currents were filtered at $2 \mathrm{kHz}$ through a 4-pole low-pass Bessel filter and digitized at $5 \mathrm{kHz}$. The experiments were controlled using pClamp 5.6 or 10.0 software(s) and analyzed using Clampfit 6.0 .3 or 10.0. Current recordings were performed in bath solution superfused with the following solution containing (in mmol/L): $\mathrm{CaCl}_{2}$ 2, 4-aminopyridine 5, tetraethylammonium (TEA)-Cl 136, $\mathrm{MgCl}_{2} 1.1$, HEPES 25, and glucose 22 (pH adjusted to 7.4 with TEA-OH). ${ }^{24}$ The pipette solution contained (in mmol/L): cesium aspartate 100, $\mathrm{CsCl} 20, \mathrm{MgCl}_{2} 1, \mathrm{Mg}$-ATP 2, $\mathrm{Na}_{2}-$ GTP 0.5, EGTA 5, HEPES 5 (pH adjusted to 7.3 with $\mathrm{CsOH}$ ). To separate the LVACC $\left(\mathrm{I}_{\mathrm{Ca}, \mathrm{T}}\right)$ from high voltage activated L-type $\mathrm{Ca}^{2+}$ currents $\left(\mathrm{HVACC}, \mathrm{I}_{\mathrm{Ca}, \mathrm{L}}\right)$ a subtraction protocol was used: depolarizing voltage steps from holding potential (HP) of $-100 \mathrm{mV}$ elicit both $\mathrm{I}_{\mathrm{Ca}, \mathrm{L}}$ and $\mathrm{I}_{\mathrm{Ca}, \mathrm{T}}\left(\mathrm{I}_{\mathrm{Ca}, \text { total }}\right)$; from $-50 \mathrm{mV}$ only $\mathrm{I}_{\mathrm{Ca}, \mathrm{L}}$ current is activated. The difference 
between current traces at $\mathrm{HP}$ of -50 and at $-100 \mathrm{mV}$ for each potential reflects the theoretical $\mathrm{I}_{\mathrm{Ca}, \mathrm{T}}$.

$\mathrm{I}_{\mathrm{Ca}, \mathrm{L}}$ and $\mathrm{I}_{\mathrm{Ca}, \mathrm{T}}$ were measured by applying depolarizing voltage steps (380ms or $400 \mathrm{~ms}$ ) from $-70 \mathrm{mV}$ to $+60 \mathrm{mV}$ and $-40 \mathrm{mV}$ to $+60 \mathrm{mV}$, respectively, in $10 \mathrm{mV}$ increments.

Current density-voltage $(I-V)$ curves were fitted using a modified Boltzmann equation $I=$ $\left(\mathrm{A} 2+(\mathrm{A} 1-\mathrm{A} 2) /\left(1+\exp \left(\left(\mathrm{V}-\mathrm{V}_{0.5}\right) / \mathrm{k}\right)\right)\right) * \mathrm{G} *\left(\mathrm{~V}-\mathrm{E}_{\mathrm{rev}}\right)$ where $I$ is the current for the test potential $V, V_{\text {rev }}$ is the $\mathrm{Ca}^{2+}$ current reversal potential, $G$ is the maximal low-voltage-activated (LVA) or high-voltage-activated (HVA) conductance, $V_{0.5}$ is potential for half-maximal activation, and $k$ is related to the steepness of the voltage dependence of activation. The obtained parameters of $\mathrm{G}_{\max }$ (maximal conductance) and $\mathrm{V}_{\text {rev }}$ (reversal potential) were then used to calculate fractional conductance $\left(\mathrm{G} / \mathrm{G}_{\max }\right)$ at each $\mathrm{V}_{\mathrm{m}}$ using the equation: $\mathrm{G} /$ $\mathrm{G}_{\max }=\mathrm{I}_{\mathrm{Ca}}\left[\mathrm{G}_{\max }\left(\mathrm{V}_{\mathrm{m}}-\mathrm{V}_{\text {rev }}\right)\right]$ where $\mathrm{G}$ is the total macroscopic conductance at $\mathrm{V}_{\mathrm{m}}$. The $G-V$ curves were plotted with the values obtained from the fit of the $I-V$ curves using the following form of the Boltzmann equation: $\mathrm{G} / \mathrm{G}_{\max }=\mathrm{I} /\left\{1+\exp \left[-\left(\mathrm{V}_{\mathrm{m}}-\mathrm{V}_{0.5}\right) / \mathrm{k}\right]\right\}$ where $\mathrm{V}_{\mathrm{m}}$ is the membrane potential, $V_{0.5}$ the membrane potential at half maximal activation and $k$ is the slope factor. ${ }^{25}$ The current density was calculated by dividing the current amplitude by the cell capacitance.

The time course was determined in individual cells using the double exponential fits (Chebyshev algorithm of CLAMPFIT6.03) to the decay phases of the currents by the equation: $\mathrm{I}(\mathrm{t})=\mathrm{A}_{\text {fast }}\left[\exp \left(-\mathrm{t} / \boldsymbol{\tau}_{\text {fast }}\right]+\mathrm{A}_{\text {slow }}\left[\exp \left(-\mathrm{t} / \boldsymbol{\tau}_{\text {slow }}\right)\right]+\mathrm{A} . \mathrm{A}_{\text {fast }}, \mathrm{A}_{\text {slow }}\right.$ and $\boldsymbol{\tau}_{\text {fast }}, \boldsymbol{\tau}_{\text {slow }}$ are being the maximal amplitude and time constants of the fast and slow components of inactivation, respectively. A is being the remaining current.

\section{Surgical models}

Two-month old wild-type (Wt) and $\mathrm{Ca}_{\mathrm{v}} 3.1^{-/-}$mice were subjected to transverse aortic constriction (TAC) or sham procedures under anesthesia by $3 \%$ isoflurane as previously described. ${ }^{16,26,27} \mathrm{Wt}$ and $\mathrm{Ca}_{\mathrm{v}} 3.1^{-/-}$mice were bred onto the C57BL/6J background. For chronic $\beta$-adrenergic stimulation, Alzet miniosmotic pumps (Model 2002; DURECT Corp., Cupertino, CA, USA) containing a mixture of isoproterenol (Iso-pump) $(60 \mathrm{mg} / \mathrm{kg} / \mathrm{day})$ or physiological buffer solution (PBS, vehicle control) were surgically inserted dorsally and subcutaneously in 2-month-old mice under isoflurane (2\%) anesthesia as previously described. ${ }^{27}$ Experiments involving animals were approved by the Institutional Animal Care and Use Committee of Cincinnati Children's Hospital and University of Cincinnati.

SH/NH and TAC (Sprague Dawley) rats were purchased from Harlan Laboratories.

\section{Chemicals}

Mibefradil (Roche) and Tetrodotoxin (TTX) were dissolved in water as $10 \mathrm{mmol} / \mathrm{L}$ stocks and stored in aliquots at $-20^{\circ} \mathrm{C}$, and directly dissolved in the external recording solution to the appropriate concentration before use. $\mathrm{NiCl}_{2}$ was dissolved in water as a $1.0 \mathrm{~mol} / \mathrm{L}$ stock and diluted into the recording solution to the appropriate concentration. Nifedipine was dissolved in ethanol. 
All reagents were purchased from Sigma (St. Louis, MO) unless otherwise specified.

\section{Statistics}

All values were presented as mean \pm SEM. Means between 2 groups were compared using the unpaired Student's $t$ test. Differences between multiple groups were analyzed by one way ANOVA. Difference of $\mathrm{p}<0.05$ were considered statistically significant

\section{RESULTS}

Electrophysiological and pharmacological characterization of $\mathrm{Ca}_{\mathrm{v}} 3.1\left(\mathrm{a}_{1 \mathrm{G}}\right)$-transgenic $(\mathrm{Tg})$ mice

Recent studies have supported the concept that alterations in $\mathrm{I}_{\mathrm{Ca}, \mathrm{T}}$ contributes to the development of cardiac dysfunction. Accordingly, the EP characterization of the newly developed (over-expressed) $\mathrm{Ca}_{\mathrm{v}} 3.1\left(\mathrm{a}_{1 \mathrm{G}}\right)$-Tg mice is logical.

$\mathrm{I}_{\mathrm{Ca}}$ was recorded from freshly isolated 3 month old $\mathrm{Ca}_{\mathrm{v}} 3.1-\mathrm{Tg}$ VMs. TTX was not included in the recording solution, assuming that $\mathrm{Na}^{+}$contamination from the Tyrode solution used for the VMs isolation is negligible and the use of a $\mathrm{Na}^{+}$-free solution eliminates potential interference with $\mathrm{I}_{\mathrm{Na}}$. Figure $1 \mathrm{~A}$ represents mean mixed current-voltage relationships ( $I-V$ curve) of $\mathrm{I}_{\mathrm{Ca}, \mathrm{T}}$ and $\mathrm{I}_{\mathrm{Ca}, \mathrm{L}}$ simultaneously present at a $\mathrm{HP}-100 \mathrm{mV}$ as well as the $I-V$ curve of $\mathrm{I}_{\mathrm{Ca}, \mathrm{L}}$ at a $\mathrm{HP}$ of $-50 \mathrm{mV}$ in $\mathrm{Ca}_{\mathrm{v}} 3.1-\mathrm{Tg}$ and $\mathrm{Ntg}(\mathrm{tTA})^{28} \mathrm{VMs}$ (Fig. 1C). The voltage dependence of $\mathrm{I}_{\mathrm{Ca}}$ activation was also examined as described previously. ${ }^{25}$ The Boltzmann curves are illustrated in Fig. $1 \mathrm{~B}\left(\mathrm{~V}_{0.5}=7.1 \mathrm{mV}\right.$ and $-42.4 \mathrm{mV} ; \mathrm{k}=9.3 \mathrm{mV}$ and $5.4 \mathrm{mV}$ for $\mathrm{Ca}_{\mathrm{v}} 3.1-\mathrm{Tg}$ at $\mathrm{HP}-50 \mathrm{mV}$ and $-100 \mathrm{mV}$ (subtracted), respectively). Figure 1D and $\mathrm{E}$ illustrate representative recordings of $\mathrm{I}_{\mathrm{Ca} \text {,total }}$ and $\mathrm{I}_{\mathrm{Ca}, \mathrm{L}}$ for $\mathrm{Ca}_{\mathrm{v}} 3.1-\mathrm{Tg}$ and Ntg. For test potentials (TP) above $-20 \mathrm{mV}$, an L-type current is activated that displays maximum amplitude near $+20 \mathrm{mV}$ $(-6.0 \pm 0.52 \mathrm{pA} / \mathrm{pF}, \mathrm{n}=26)$. Averaged peak $I-V$ relationships demonstrate attenuation of $\mathrm{I}_{\mathrm{Ca}, \mathrm{L}}$ in $\mathrm{Ca}_{\mathrm{v}} 3.1-\mathrm{Tg}$. Theoretically, at a $\mathrm{HP}$ of $-50 \mathrm{mV}, \mathrm{I}_{\mathrm{Ca}, \mathrm{T}}$ is mostly inactivated whereas the $\mathrm{I}_{\mathrm{Ca}, \mathrm{L}}$ remains almost unaffected. This indicates that there is no significant contribution of L-type current at a depolarization of -30 and $-40 \mathrm{mV}$, whereas $\mathrm{I}_{\mathrm{Ca}, \mathrm{T}}$ is maximally activated (TP $-30 \mathrm{mV}:-19.5 \pm 1.7 \mathrm{pA} / \mathrm{pF},\left(\mathrm{P}<0.001\right.$ vs. $\left.\left.\mathrm{I}_{\mathrm{Ca}, \mathrm{L}}\right)\right)$. Depolarizing voltage steps from the $\mathrm{HP}$ of $-100 \mathrm{mV}$ elicited both $\mathrm{I}_{\mathrm{Ca}, \mathrm{L}}$ and $\mathrm{I}_{\mathrm{Ca}, \mathrm{T}}(-19.8 \pm 1.7 \mathrm{pA} / \mathrm{pF})$.

At the same time, the cell capacitance indicates no increase (rather a decrease) in cell size compared with tTA-Ntg VMs $(171.5 \pm 5.6 \mathrm{pF}, \mathrm{n}=64 / 9$ and $187.0 \pm 4.9 \mathrm{pF}, \mathrm{n}=66 / 7$, respectively $\left(\mathrm{p}=0.041 \mathrm{vs}\right.$. $\mathrm{Ntg}$ ). This supports the findings that $\mathrm{Ca}_{\mathrm{v}} 3.1-\mathrm{Tg}$ mice do not develop cardiac dysfunction during the first 12 months of life. ${ }^{13}$

\section{Effect of $\mathrm{NiCl}_{2}$ and Mibefradil on $\mathrm{I}_{\mathrm{Ca}, \mathrm{L}}$ and $\mathrm{I}_{\mathrm{CaT}}$ in $\mathrm{Ca}_{\mathrm{v}} 3.1-\mathrm{Tg}$ mice}

$\mathrm{Ni}^{2+}\left(\mathrm{NiCl}_{2}\right)$ and Mibefradil (Mib) have been used to distinguish between LVDCC and HVDCC. In fetal cardiomyocytes, $200 \mu \mathrm{mol} / \mathrm{L} \mathrm{NiCl}_{2}$ blocks the $\mathrm{Ca}_{\mathrm{v}} 3.1$ channel current by $\sim 50 \%$; in contrast, $\sim 10 \mu \mathrm{mol} / \mathrm{L} \mathrm{Ni}^{2+}$ is sufficient to completely block the $\mathrm{Ca}_{\mathrm{v}} 3.2 .^{29}$

Representative current traces are shown in Fig. 1F. High concentrations of $\mathrm{Ni}^{2+}(500 \mu \mathrm{mol} / \mathrm{L})$ almost completely blocked the current at $\mathrm{HP}$ of $-100 \mathrm{mV}(84.3 \pm 1.0 \%, \mathrm{n}=7)$, suggesting that the $\mathrm{Ca}_{\mathrm{v}} 3.1$ gene product is likely responsible for most $\mathrm{I}_{\mathrm{Ca}, \mathrm{T}}$ in these cells (Fig. $1 \mathrm{~F}, \mathrm{G}$ ). 
Mibefradil was originally introduced as a "selective" T-type $\mathrm{Ca}^{2+}$ channel blocker, although this drug also inhibits $\mathrm{I}_{\mathrm{Ca}(\mathrm{TTX})}$ in guinea pig ventricular myocytes and partially inhibits LVDCCs. ${ }^{22,}{ }^{30}$ Nifedipine (Nif) was used to eliminate $\mathrm{I}_{\mathrm{Ca}, \mathrm{L}}$. The $\mathrm{I}_{\mathrm{Ca} \text {,total }}$ was measured using a HP of $-100 \mathrm{mV}$, and then $100 \mu \mathrm{mol}$ Nif was added to the perfusion solution to eliminate $\mathrm{I}_{\mathrm{Ca}, \mathrm{L}}$. The remaining current was taken as $\mathrm{I}_{\mathrm{Ca}, \mathrm{T}}$. Nifedipine inhibited $\mathrm{I}_{\mathrm{Ca}}$ by $28.6 \pm 6.3 \%$ from a $\mathrm{HP}$ of $-100 \mathrm{mV}$ and by $82.1 \pm 5.9 \%(\mathrm{n}=5)$ from $\mathrm{HP}$ of $-50 \mathrm{mV}$.

Figure $2 \mathrm{~A}$ and $\mathrm{B}$ display representative $\mathrm{I}_{\mathrm{Ca} \text {,total }}$ in the absence and presence of $200 \mu \mathrm{mol} / \mathrm{L}$ $\mathrm{NiCl}_{2}$. $\mathrm{Ni}^{2+}$ significantly affected voltage-dependence of $\mathrm{I}_{\mathrm{Ca}}$, activation at $\mathrm{HP}$ of $-100 \mathrm{mV}$ (subtracted $\left.\mathrm{I}_{\mathrm{Ca}, \mathrm{T}}\right)$ as seen in Fig. $2 \mathrm{C}$ and $\mathrm{D}\left(\mathrm{V}_{0.5}=-44.3 .1 \mathrm{mV}\right.$ and $-35.9 \mathrm{mV} ; \mathrm{k}=1.0$ and $9.7 \mathrm{mV}$ for $\mathrm{Ca}_{\mathrm{v}} 3.1-\mathrm{Tg}$ before and after $200 \mu \mathrm{mol} / \mathrm{L} \mathrm{NiCl}_{2}$, respectively). At a $\mathrm{HP}$ of $-50 \mathrm{mV}$ the activation curve was slightly shifted left $\left(\mathrm{V}_{0.5}=-40.7 \mathrm{mV}\right.$ and $-37.01 \mathrm{mV} ; \mathrm{k}=6.0$ and 9.0mV for $\mathrm{Ca}_{\mathrm{v}} 3.1-\mathrm{Tg}$ before and after $\mathrm{NiCl}_{2}$, respectively) (Fig. 2E, F). These results are in good agreement with data demonstrated by Lacinova and co-workers. ${ }^{31}$ Mibefradil also caused a slight shift of activation curve in a positive direction between -40 and $-20 \mathrm{mV}$ from $\mathrm{HP}-100 \mathrm{mV}$ indicating $\mathrm{I}_{\mathrm{Ca}, \mathrm{T}}$ reduction $\left(\mathrm{V}_{0.5}=-39.9 \mathrm{mV}\right.$ and $-36.7 \mathrm{mV} ; \mathrm{k}=5.4$ and $8.6 \mathrm{mV}$ for $\mathrm{Ca}_{\mathrm{v}} 3.1-\mathrm{Tg}$ before and after $3 \mu \mathrm{mol} / \mathrm{L}$ Mib, respectively) (Fig. 4G, J, K). Of note, in cardiomyocytes, inadequacies in the activation curve is due to the fact that it is almost impossible to separate $\mathrm{I}_{\mathrm{Ca}, \mathrm{T}}$ from $\mathrm{I}_{\mathrm{Ca}, \mathrm{L}}$ and as a consequence the $\mathrm{V}_{\text {rev }}$ cannot be determined accurately.

\section{Isoproterenol-induced cardiac hypertrophy in Wt and in Cav3.1 ${ }^{-/-}-\mathrm{KO}$ mice: ventricular cardiomyocytes lack of $\mathrm{I}_{\mathrm{Ca}, \mathrm{T}}$ and exhibit $\mathrm{I}_{\mathrm{Ca}(\mathrm{TTX})}$}

Further addressing the issue of re-expression of $\mathrm{I}_{\mathrm{Ca}, \mathrm{T}}, \mathrm{Wt}$ (1. group) (Fig. 3A) and $\mathrm{Ca}_{\mathrm{v}} 3.1^{-/-}$(2. group) (Fig. 3B) mice were treated with Iso for 11 days. In the third group, Wt mice were implanted with osmotic mini-pumps containing a mixture of PBS (vehicle control) (Fig. 3C). The $\mathrm{Na}^{+}$-channel blocker TTX was omitted from the recording solution. In our study among the $60 \mathrm{VMs}$ from the 11 days $\mathrm{Wt}$ and $\mathrm{Ca}_{\mathrm{v}} 3 \cdot 1^{-/-}$Iso-pump implanted mice, 50 of them exhibited a LVA inward current at membrane potentials negative to the $\mathrm{I}_{\mathrm{Ca}, \mathrm{L}}$ activation threshold. In VMs isolated from $\mathrm{Ca}_{\mathrm{v}} 3.1^{-/-}$Iso-pump, the LVA inward current peaked at $\sim-40 \mathrm{mV}$ and had a maximal current density of $-0.52 \pm 0.05 \mathrm{pA} / \mathrm{pF}(\mathrm{n}=31 / 4)$ (Fig. 3D). The "T-type like" $\mathrm{Ca}^{2+}$ current of Wt after 11 days of Iso-pump showed a similar current density of $-0.48 \pm 0.07 \mathrm{pA} / \mathrm{pF}(\mathrm{n}=30 / 3)$. (After 4 days infusion of Iso, the average LVA inward current was $-0.21 \pm 0.05 \mathrm{pA} / \mathrm{pF}(\mathrm{n}=18 / 2))$. These findings initially appear consistent with the proposal that the $\mathrm{I}_{\mathrm{Ca}, \mathrm{T}}$ is re-expressed in pathological heart conditions. In order to confirm that the expressed LVA inward currents (which we assumed to be "T-type like" because of the kinetics of the current), observed in the Iso group are $\mathrm{I}_{\mathrm{Ca}, \mathrm{T}}$, the vehicle group was also examined. We predicted that there would be a lack of the $\mathrm{LVA} \mathrm{Ca}^{2+}$ current in the VMs from the Wt-PBS group. To our surprise, in the PBS-control VMs the LVA inward peak currents densities at $-60,-50,-40$ and $-30 \mathrm{mV}$ TPs were comparable to the Iso treated groups and no significant differences were found among the 3 groups (Fig. 3 C, D). As anticipated, VMs isolated from $\mathrm{Wt}$ and $\mathrm{Ca}_{\mathrm{v}} 3 \cdot 1^{-/-}$hearts after Iso treatment were hypertrophied by $\sim 23 \%$ and $\sim 17 \%$, respectively compared with PBS-control presenting a clear indication for cardiac remodeling on a single cell level reflected by increased cell capacitance (Fig. 3E). Unexpectedly, these results suggest, that the LVA inward currents, 
observed at a HP of $-100 \mathrm{mV}$ in all three groups, are not associated with the development of hypertrophy. Finally, it was important to determine if the LVA inward current is indeed the LVACC.

\section{Pharmacological characterization of "T-type like" inward current}

Figure 4A and B (left panels) illustrates the effects of $200 \mu \mathrm{mol} / \mathrm{L} \mathrm{NiCl}_{2}$ at two different HPs. The LVA inward currents showed absolutely no sensitivity to $\mathrm{Ni}^{2+}$, while the $\mathrm{I}_{\mathrm{Ca}, \mathrm{L}}$ was predictably depressed by $\sim 50 \%$. Figure $4 \mathrm{C}$ illustrates the time-dependent effect of $\mathrm{NiCl}_{2}$ on LVA inward current. Surprisingly, this $\mathrm{Ni}^{2+}$-insensitive current was completely suppressed by $30 \mu \mathrm{mol} / \mathrm{L}$ TTX (Fig. 4B, middle panel). TTX does not influence $\mathrm{I}_{\mathrm{Ca}, \mathrm{T}}$ although it has been shown that it blocks $\mathrm{I}_{\mathrm{Ca}, \mathrm{L}}$ in VCs. ${ }^{32}$ The other unusual characteristic of this LVA inward current, which differs from $\mathrm{I}_{\mathrm{Ca}, \mathrm{T}}$, is that it was undetectable during the first 5-6 minutes after establishing whole cell configuration. After applying repetitive depolarizations the inward current amplitude started to increase ("run-up") (Fig. 4D). This observation is in good agreement with an earlier report by Heubach et al. ${ }^{22}$

Based on our experiments we conclude that the LVA inward current is not $\mathrm{I}_{\mathrm{Ca}, \mathrm{T}}$, but rather strongly resembles the distinct characteristics of $\mathrm{I}_{\mathrm{Ca}(\mathrm{TTX})}$ through the $\mathrm{Na}^{+}$channel. At the $\mathrm{HP},-50 \mathrm{mV}, \mathrm{I}_{\mathrm{Ca}, \mathrm{L}}$ was slightly depressed by $10 \mu \mathrm{mol} / \mathrm{L}$ Mib (Fig. 4A, B) although, we failed to observe any significant effect on LVA inward currents. However, the addition of $20 \mu \mathrm{mol} / \mathrm{L}$ Mib did reduce the amplitude of the LVA inward current. Figure 4E summarizes the effect of various compounds on the HVACC and the LVA inward current.

Inactivation kinetics are thought to be slower in $\mathrm{I}_{\mathrm{Ca}(\mathrm{TTX})}$ than in the classical cardiac $\mathrm{I}_{\mathrm{Na}} \cdot{ }^{21}$ The time constant of inactivation $(\tau)$ is described by a two-exponential fit. Values of taus ( $\tau$, fast and slow) were determined for $\mathrm{I}_{\mathrm{Ca}(\mathrm{TTX})}$ measured in $\mathrm{Wt}$ and $\mathrm{Ca}_{\mathrm{v}} 3.1^{-/-}$mice after Isotreatment and in Wt mice after vehicle treatment (Fig. 4F). Our data are entirely comparable with Alvarez et al. ${ }^{21}$ results generated in rats after long-term myocardial infarction using $5.5 \mathrm{mmol} / \mathrm{L} \mathrm{Ca}^{2+}$ as charge carrier through sodium channel that may not be the so-called "window current" channel.

Since we were unable to record LVACC after the Iso-treatment in Wt and $\mathrm{Ca}_{\mathrm{v}} 3.1^{-/-} \mathrm{VMs}$, we further explored a putative role for the T-type channel in other diseased states.

\section{Pressure overload-induced cardiac hypertrophy after TAC in Wt and in $\mathrm{Ca}_{\mathrm{v}} 3^{3.1^{-/}-\mathrm{KO}}$ mice: failure to record $\mathrm{I}_{\mathrm{Ca}, \mathrm{T}}$ but detection of $\mathrm{I}_{\mathrm{Ca} \text { (TTX) }}$}

It is currently believed that re-expression of $\mathrm{I}_{\mathrm{Ca}, \mathrm{T}}$ is associated with chronic pressure overload-induced left ventricular hypertrophy in several species, but there are very limited published data for the mouse. Wt and $\mathrm{Ca}_{\mathrm{v}} 3 \cdot 1^{-/-}$mice were subjected to TAC and were followed for 5, 11 and 50 days. TAC elicited a $40 \%$ increase in HW/BW ratio two weeks after the procedure. Pressure gradients were measured by Doppler (echocardiography) and were around 50-60mmHg for all mice. This model did induce slight cardiac dysfunction after 2 weeks; the fractional shortenings were about 35-40\%. In the presence of TTX neither macroscopic inward $\mathrm{I}_{\mathrm{Ca}, \mathrm{T}}$ nor $\mathrm{I}_{\mathrm{Ca}(\mathrm{TTX})}$ were detected in the hypertrophied VMs. Figure 5A and $\mathrm{B}$ shows current-voltage $(I-V)$ relations of mean values of $\mathrm{I}_{\mathrm{Ca}}$ density at $\mathrm{HP}$ of -50 and $-100 \mathrm{mV}$ after 5 and 11 days of TAC, respectively. Figure 5C shows typical representative 
recordings of $\mathrm{I}_{\mathrm{Ca}}$ in VMs isolated from $\mathrm{Ca}_{\mathrm{v}} 3.1^{-/-}$mice at different HPs after 11 days of TAC. Figure 5D shows a superimposed $I-V$ plot of $\mathrm{I}_{\mathrm{Ca}}$ at $\mathrm{HP}$ of -50 and $-100 \mathrm{mV}$.

Based on our observations with Iso-groups we were convinced that $\mathrm{I}_{\mathrm{Ca}(\mathrm{TTX})}$ could be also detected in mouse heart subjected to TAC. To provide a direct proof for this assumption, TTX was omitted from the recording solution. Indeed, LVA inward current appeared in VMs isolated from both Wt-TAC and $\mathrm{Ca}_{\mathrm{v}} 3 \cdot 1^{-/-}$-TAC mice and resembled the characteristics of the $\mathrm{I}_{\mathrm{Ca} \text { (TTX) }}$ previously discussed in the Iso-group mice (Fig. 5E, left panel). After switching to the TTX containing solution, the LVA currents were abolished.

In addition, three $\mathrm{Tg}$ hypertrophy mouse models were investigated: $\mathrm{Ca}_{\mathrm{v}} 1.2 \mathrm{a}_{1 \mathrm{C}}{ }^{18}$, $\mathrm{a}$ TM(Glu54Lys) ${ }^{20}$ and the Calcineurin. ${ }^{19}$ Despite the fact that cardiomyocyte hypertrophy on a single cell level was confirmed by the increased cell capacitance compared with $\mathrm{Ntg}$ (Wt mouse data are also pooled in) (Fig. 6A), we failed to record cardiac $\mathrm{I}_{\mathrm{Ca}, \mathrm{T}}$ (data not shown).

\section{SHR 5 and 11 weeks old with cardiac hypertrophy: VMs lack $I_{C a, T}$ and exhibit $I_{C a(T T X)}$}

We further tested the SHR model, at 5 and 11 weeks (data are not shown) of age and demonstrated only $\mathrm{I}_{\mathrm{Ca}(\mathrm{TTX})}$ current in absence of TTX, and no evidence of $\mathrm{I}_{\mathrm{Ca}, \mathrm{T}}$ (Fig. 6 B).

\section{$\mathrm{I}_{\mathrm{Ca}, \mathrm{T}}$ recorded in ventricular cardiomyocytes isolated from TAC rat model}

Further, we examined TAC rats ( $2 \mathrm{wk}$ ). We could record $\mathrm{I}_{\mathrm{Ca}, \mathrm{T}}$ in two out of twenty four cells measured, a sign that $\mathrm{I}_{\mathrm{Ca}, \mathrm{T}}$ is involved in electrical remodeling $(-0.39 \mathrm{pA} / \mathrm{pF}(-30 \mathrm{mV}$ at $\mathrm{HP}-100 \mathrm{mV}$ ). The peak $\mathrm{I}_{\mathrm{Ca}, \mathrm{L}}$ was $-5.8 \pm 0.25 \mathrm{pA} / \mathrm{pF}$ (at $+20 \mathrm{mV}$ ) comparable with the $\mathrm{Wt}$ $-5.6 \pm 0.33 \mathrm{pA} / \mathrm{pF}$ (Fig. $6 \mathrm{C}, \mathrm{D}$ ). The cell capacitance was significantly higher in the TAC rats compared with Wts confirming cellular remodeling $(342.3 \pm 11.2 \mathrm{pF}$ vs. $277.3 \pm 18.7 \mathrm{pF}$, respectively, $(\mathrm{p}<0.05$ vs. Wt).

\section{DISCUSSION}

It has been reported that $\mathrm{I}_{\mathrm{Ca}, \mathrm{T}}$ reappears in hypertrophied, post-infarction and cardiomyopathic ventricular myocytes. ${ }^{4,5,7,8}$

\section{Possible role for the $\mathrm{Ca}_{\mathrm{v}} 3.2$ channel in the development of cardiac remodeling}

The first part of the electrophysiological experiments was designed to confirm that overexpression of the $\mathrm{Ca}_{\mathrm{v}} 3.1$ gene in the heart could lead to overexpression of functional Ttype $\mathrm{Ca}^{2+}$ channel which is reflected by the appearance of $\mathrm{I}_{\mathrm{Ca}, \mathrm{T}}$ in VMs. We identified both LVACC and HVACC in VMs from $\mathrm{Ca}_{\mathrm{v}} 3.1-\mathrm{Tg}$ mice. ${ }^{13}$ Surprisingly, this Tg mouse model, despite the huge $\mathrm{I}_{\mathrm{Ca}, \mathrm{T}}$ density and increased $\mathrm{Ca}^{2+}$-transients (unpublished data are not shown), did not develop cardiac hypertrophy or demonstrate any sign of compromised cardiac function during its life span ${ }^{16}$ consistent with previous observations by Jaleel et al. ${ }^{13}$

The second part of the present study was aimed to determine whether increased ventricular $\mathrm{I}_{\mathrm{Ca}, \mathrm{T}}$ contributes to the progression of cardiac hypertrophy in diseased models. To accomplish this, comprehensive patch clamp experiments were carried out in an attempt to 
confirm published findings related to the reappearance of $\mathrm{I}_{\mathrm{Ca}, \mathrm{T}}$ in adult $\mathrm{VMs}$ in $\mathrm{HT}$ or HF. ${ }^{5,7-10}$

We consistently recorded LVA inward currents in cardiomyocytes isolated from Wt and $\mathrm{Ca}_{\mathrm{v}} 3.1^{-1-}$ mice implanted with Iso-pumps. However, while the LVA currents resembled the properties of $\mathrm{I}_{\mathrm{Ca}, \mathrm{T}}$, there was a lack of sensitivity to $\mathrm{Ni}^{2+}$, even as high as $200 \mu \mathrm{mol} / \mathrm{L}$. The most important and main finding was that Wt VMs, derived from mice previously implanted with osmotic mini-pumps containing PBS, also expressed "T-type like" current with a current density comparable to that obtained in hypertrophied VMs after Iso-treatment (and/or pressure overload).

\section{What channel could be responsible for the occurrence of the "T-type like" current?}

Pharmacological analysis of the LVA inward current proves that the classic cardiac T-type channel is not involved since the current was completely abolished by $30 \mu \mathrm{mol} / \mathrm{L}$ TTX. As a result, this has led us to conclude that the inward current we observed at HP of $-100 \mathrm{mV}$, displays the distinct characteristics of $\mathrm{I}_{\mathrm{Ca}(\mathrm{TTX})}{ }^{21,} 33$ Despite the absence of TTX, we were unable to detect macroscopic $\mathrm{I}_{\mathrm{Ca}, \mathrm{T}}$ in control mice (tTA-Ntg). Therefore, LVACC current measured predominantly through the overexpressed $\mathrm{Ca}_{\mathrm{v}} 3.1$ channel was not contaminated by other LVA inward currents.

\section{What is the significance of this TTX-sensitive $\mathrm{I}_{\mathrm{Ca}}$ ?}

Although $\mathrm{Na}^{+}$is the main permeant ion through voltage- and TTX-sensitive cardiac $\mathrm{Na}^{+}$ channels under physiological conditions, several studies have described $\mathrm{I}_{\mathrm{Ca}}$ (TTX) as a "new $\mathrm{Na}^{+}$current component". It appears that the $\mathrm{I}_{\mathrm{Ca}(\mathrm{TTX})}$ channels are distinct from the classical cardiac $\mathrm{Na}^{+}$channels, as first documented in the rat hippocampal CA1 region. ${ }^{21}$ Cole et al. ${ }^{34}$ proposed that under specific experimental conditions, 1) the absence or near absence of external $\mathrm{Na}^{+}$, and 2) the presence of external calcium, $\mathrm{Ca}^{2+}$ ions would permeate $\mathrm{Na}^{+}$ channels in guinea pig VMs. Based on this proposal, $\mathrm{I}_{\mathrm{Ca}(\mathrm{TTX})}$ was attributable to the conversion of classic $\mathrm{Na}^{+}$channels. In another study, using rat VMs in presence of normal $\mathrm{Na}^{+}$concentration, the authors reported that activation of the $\beta$-AR or protein-kinase $A$, the $\mathrm{Na}^{+}$channel was transformed into "promiscuous" cardiac $\mathrm{Na}^{+}$channels permitting $\mathrm{Ca}^{2+}$ to pass (slip-mode conductance). ${ }^{35}$ We have no evidence to support or deny this concept. Experimental data in rat ventricular myocytes ${ }^{33}$ suggest that $\mathrm{I}_{\mathrm{Ca}(\mathrm{TTX})}$ represents a "new cardiac $\mathrm{Na}^{+}$channel" distinct from classical $\mathrm{Na}^{+}$channels expressing slower activating and inactivating kinetics. Interestingly, the pharmacological profile resembles $\mathrm{Na}^{+}$rather than $\mathrm{Ca}^{2+}$ channels. Adding to the complexity, Sun et al. ${ }^{36}$ using canine atrial myocytes, showed that TTX did interact with $\mathrm{I}_{\mathrm{Ca}, \mathrm{T}}$ in a very peculiar way, viz.: TTX attenuated the efficacy of $\mathrm{Ni}^{2+}$-induced block of $\mathrm{I}_{\mathrm{Ca}, \mathrm{T}}$. These results implicate the presence of common toxin-binding sites on $\mathrm{I}_{\mathrm{Ca}, \mathrm{T}}, \mathrm{I}_{\mathrm{Na}} \cdot \mathrm{I}_{\mathrm{Ca}(\mathrm{TTX})}$ has been observed in several species including rat, ${ }^{33}$ guinea pig, ${ }^{22,34,37}$ and in human. ${ }^{38}$ Moreover, Alvarez et al. ${ }^{21}$ demonstrated the occurrence of $\mathrm{I}_{\mathrm{Ca}(\mathrm{TTX})}$ like current in cardiomyocytes from post-myocardial infarcted hearts but not in cardiomyocytes from young and sham hearts. In summary, the classical cardiac $\mathrm{Na}^{+}$ channels are more frequent than $\mathrm{I}_{\mathrm{Ca}(\mathrm{TTX})}$ channels, however these channels may play a critical role in triggering and conducting of the ventricular action potential. It is also possible that $\mathrm{I}_{\mathrm{Ca}(\mathrm{TTX})}$ channels have importance in the generation of arrhythmias. However, the 
physiological impact of these channels in different hypertrophy models presented here remains to be explored.

The molecular identity of $\mathrm{I}_{\mathrm{Ca} \text { (TTX) }}$ remains obscure. Strategies to elucidate its exact nature include systematic characterization of TTX- and $\mathrm{Ni}^{2+}$-sensitivity of all $\mathrm{Na}^{+}$and $\mathrm{Ca}^{2+}$ channel subunits expressed in the murine myocardium; considering also putative posttranslational modifications that may have occurred during remodeling. The degree of block needs to be assessed in light of the voltage-dependence of block (presumably conductance results) by TTX and $\mathrm{Ni}^{2+}$. However, we do not advise the use of Mibefradil, as it is not sufficiently selective for a specific $\mathrm{Ca}^{2+}$ channel subtype (it impairs $\mathrm{I}_{\mathrm{Ca}(\mathrm{TTX})}$ also) ${ }^{22}$ and it has strong voltage- and use-dependent block of $\mathrm{I}_{\mathrm{Ca}, \mathrm{L}}\left(\text { and } \mathrm{Na}_{\mathrm{v}} 1.5\right)^{30,39}$ that would make interpretation difficult.

Another approach that can be used when elucidating the molecular identity of $\mathrm{I}_{\mathrm{Ca}(\mathrm{TTX})}$ in mouse VMs includes adjusting the recording solutions as follows: $\mathrm{Cs}^{+}$(it has been shown to permeate $\mathrm{Na}^{+}$but not $\mathrm{Ca}^{2+}$ channels) is used in the recording solution instead of $\mathrm{TEA}^{+}$as the $\mathrm{Na}^{+}$replacement to prove that $\mathrm{I}_{\mathrm{Ca} \text { (TTX) }}$ is attributable to $\mathrm{Ca}^{2+}$ influx through the cardiac $\mathrm{Na}^{+}$channels. The higher peak $\mathrm{I}_{\mathrm{Ca}(\mathrm{TTX})}$ in the presence of $\mathrm{Cs}^{+}$suggest that $\mathrm{I}_{\mathrm{Ca}(\mathrm{TTX})}$ is mostly due to $\mathrm{Ca}^{2+}$ flux through the cardiac $\mathrm{Na}^{+}$channel. ${ }^{21,33,38,39}$ To investigate the hypothesis that $\mathrm{I}_{\mathrm{Ca} \text { (TTX) }}$ is due to a novel TTX sensitive $\mathrm{Ca}^{2+}$ channel, ${ }^{22,33}$ calcium should be replaced by an equimolar amount of barium. If $\mathrm{I}_{\mathrm{Ca} \text { (TTX) }}$ is abolished in $\mathrm{Na}^{+}$-free and $\mathrm{Ba}^{2+}$-containing recording solution, it would imply that $\mathrm{I}_{\mathrm{Ca}(\mathrm{TTX})}$ is not related to current through classical cardiac $\mathrm{Ca}^{2+}$ channels. ${ }^{38,39}$ It is well known that $\mathrm{Ba}^{2+}$ eliminates the $\mathrm{Ca}^{2+}$ dependent inactivation and modifies the inactivation of $\mathrm{I}_{\mathrm{Ca}, \mathrm{L}}$ and $\mathrm{I}_{\mathrm{Ca}, \mathrm{T}}$ differently: $\mathrm{I}_{\mathrm{Ca}, \mathrm{L}}$ became slower, $\mathrm{I}_{\mathrm{Ca}, \mathrm{T}}$ and $\mathrm{I}_{\mathrm{Ca}(\mathrm{TTX})}$ remains unaffected by $\mathrm{Ba}^{2+}$ and fast inactivation was preserved (our unpublished data). ${ }^{38}$

In addition to the above-mentioned approaches, the LabHEART computer model developed by Bers's group ${ }^{40}$ may be helpful in exploring these issues.

\section{The involvement of T-type $\mathrm{Ca}^{2+}$ currents in the progression of heart failure}

The role of T-type $\mathrm{Ca}^{2+}$ channels in the development of ventricular hypertrophy and failure is controversial and depends on the study model used. For example, Izumi et al.$^{41}$ detected $\mathrm{I}_{\mathrm{Ca}, \mathrm{T}}$ in VMs from Dahl salt sensitive rats with chronic heart failure. Low concentrations of $\mathrm{Ni}^{2+}(50 \mu \mathrm{mol} / \mathrm{L})$ inhibited the expressed $\mathrm{I}_{\mathrm{Ca}, \mathrm{T}}$ which is consistent with the sensitivity of $\mathrm{Ca}_{\mathrm{v}} 3$.2-current. In contrast, the increase in $\mathrm{Ca}_{\mathrm{v}} 3.1 \mathrm{mRNA}$ level is in discrepancy with the reported $\mathrm{Ni}^{2+}$ sensitivity. Ferron et al. ${ }^{9}$ demonstrated the re-expression of $\mathrm{I}_{\mathrm{Ca}, \mathrm{T}}$ in rat $\mathrm{VMs}$ subjected to 12 weeks of abdominal aortic stenosis. However, we have only found two papers that demonstrated the reoccurrence of LVACC in adult mouse VMs. ${ }^{10,42}$ As already pointed out, Chiang et al. ${ }^{10}$ demonstrated the reappearance of $\mathrm{Ni}^{2+}$-sensitive LVACC in VMs on pressure overload hypertrophy in Wt-mice. Their results suggest that $\mathrm{Ca}_{\mathrm{v}} 3.2$ plays an important role in the hypertrophic response via the activation of the CN-NFAT signaling pathway. However, it is puzzling that the authors were not able to demonstrate the $\mathrm{I}_{\mathrm{Ca}} \mathrm{T}$ reappearance in $\mathrm{Ca}_{\mathrm{v}} 3.1^{-/-}$mice after TAC, contrary to expectations. In line with Nakayama et al. ${ }^{16}$, Chiang et al. ${ }^{10}$ and Quang ${ }^{14}$ et al. findings also suggest that the elimination of $\mathrm{Ca}_{\mathrm{v}} 3.1$ leads to impaired cardiac function and enhanced arrhythmia vulnerability post 
myocardial infarction. The data from our study challenge Chiang's findings by demonstrating no functional expression of $\mathrm{Ni}^{2+}$ sensitive LVACC in $\mathrm{Wt}$ and $\mathrm{Ca}_{\mathrm{v}} 3.1^{-/-}$mice subjected to TAC. In the presence of TTX, we measured more than 70 cells from 6 mice after chronic TAC and we were unable to record $\mathrm{I}_{\mathrm{Ca}, \mathrm{T}}$. The discrepancy in the findings might be partly due to the differences in the cardiomyocyte condition, isolation protocol, enzymes, and different $\mathrm{Ca}^{2+}$ concentrations in the recording solution, different genetic backgrounds of experimental animals and the surgical procedures.

Since Chiang et al. ${ }^{10}$, show a close similarity of methodology with ours, one possible explanation is that $\mathrm{I}_{\mathrm{Ca}, \mathrm{T}}$ may be expressed transiently and in a small number of cardiomyocytes. Our preliminary study with TAC rats implies that maybe this is the case. Further, it is always possible that only a small fraction of cardiac cells perhaps localized to a specific region ${ }^{43}$, are involved, a possibility that is intriguing, but very difficult to resolve. The commentary of Houser ${ }^{44}$ suggests a possible connection between the T-derived calcium and the activation of CN-NFAT signaling pathway producing hypertrophy. This would be consistent with a highly specialized $\left[\mathrm{Ca}^{2+}\right]$ microdomain. Our data showing the presence of only the $\mathrm{I}_{\mathrm{Ca} \text { (TTX) }}$ do not add credibility to the hypothesis, yet the concept adumbrated by the Houser and by Chiang et al. ${ }^{10}$ paper, are still intriguing. We do not feel at this point that any of these possibilities are sufficient to explain the discrepancies. Furthermore, it is well known that the mouse cardiomyocytes are particularly difficult to voltage clamp effectively for measurements of transient currents by virtue of its extensive T-system. It is a likely possibility that sodium channels are expressed in the T-system and that the ion replacement maneuvers utilized may be somewhat ineffective. Therefore, using atrial myocytes would be more satisfactory but this was out of the scope of our studies.

\section{Plausible explanation for the presence of $\mathrm{I}_{\mathrm{Ca}(\mathrm{TTX})}$ in mouse and rat cardiomyocytes}

Since $\mathrm{I}_{\mathrm{Ca}, \mathrm{T}}$ overlaps with $\mathrm{I}_{\mathrm{Na}}$ with respect to activation and inactivation properties, a common practice is to use $\mathrm{Na}^{+}$-free recording solution. In our experiments, after cardiomyocyte isolation and prior to the electrophysiological measurements, the VMs were kept in $\mathrm{Na}^{+}$-free $\mathrm{KB}$ ("power soup") solution at $4-10^{\circ} \mathrm{C}$ until use. This could be a very important difference from other groups and perhaps provide a feasible explanation why we are able to observe $\mathrm{I}_{\mathrm{Ca} \text { (TTX) }}$ and others are not. Low temperature inhibits the sodium pump and as a consequence an accumulation of sodium occurs. When the temperature is restored to normal, the $\mathrm{Na}^{+} / \mathrm{K}^{+}$-pump activity is transiently enhanced above the control value causing hyperpolarization. The low temperature manifests by analogy the same effect of cardiac glycosides: inhibiting the extrusion of sodium from the cell and therefore the $\mathrm{K}^{+}$-uptake decreases whereas the intracellular sodium activity increases and so does calcium activity through the $\mathrm{Na}^{+} / \mathrm{Ca}^{2+}$ exchanger. It has been reported by Santana et al. ${ }^{35}$ that ouabain can activate $\mathrm{I}_{\mathrm{Ca}(\mathrm{TTX})}$ and might contribute to the ouabain-induced increase in the cardiac $\left[\mathrm{Ca}^{2+}\right]_{\mathrm{i}}$ transient. Of note, Koyama et al. ${ }^{45}$ also showed the reappearance of $\mathrm{I}_{\mathrm{Ca}, \mathrm{T}}$ in the presence of $10 \mu \mathrm{mol} / \mathrm{L}$ TTX in rat atrial myocytes after monocrotaline-induced pulmonary hypertrophy. However, it is peculiar that the recorded $\mathrm{I}_{\mathrm{Ca}, \mathrm{T}}$ current was insensitive to $100 \mu \mathrm{mol} / \mathrm{L} \mathrm{NiCl}_{2}$ which eliminates the possibility that the recorded current was indeed $\mathrm{I}_{\mathrm{Ca}, \mathrm{T}}$. Interestingly, the cardiomyocytes were also stored in $\mathrm{KB}$ solution at $4^{\circ} \mathrm{C}$ until use likewise in our protocol. 


\section{CONCLUSIONS}

The concept that has been adumbrated not only in print but in symposia is that $\mathrm{I}_{\mathrm{Ca}, \mathrm{T}}$ currents are re-expressed in cardiac dysfunction. We tried to duplicate some of these findings in mice and rats, whose hearts were compromised in various ways including genetic and thus far have been unable to show consistently the involvement of the functional $\mathrm{I}_{\mathrm{Ca}, \mathrm{T}}$ expression in the regulation and development of hypertrophy. However, during the course of our many experiments we were able to delineate the $\mathrm{I}_{\mathrm{Ca}(\mathrm{TTX})}$ current in mouse ventricular myocytes under a variety of paradigms. Our study suggests that care should be taken to account for interference by other potential ion currents when measuring and interpreting $\mathrm{I}_{\mathrm{Ca}, \mathrm{T}}$ currents in ventricular myocytes.

\section{ACKNOWLEDGMENTS}

We are pleased to thank Dr. Jeffery D. Molkentin for providing us some of the genetic models and for his support and encouragement. We are grateful to Dr. Ursula Ravens for helpful comments and suggestions.

Sources of funding: This work was supported by NIH grants HL 079599 (AS) and T-32 HL07382-35 (to A.S)

\section{REFERENCES}

1. Perez-Reyes E. Molecular physiology of low-voltage-activated t-type calcium channels. Physiol Rev. 2003; 83(1):117-161. [PubMed: 12506128]

2. Chen X, Wilson RM, Kubo H, et al. Adolescent feline heart contains a population of small, proliferative ventricular myocytes with immature physiological properties. Circ Res. 2007; 100(4): 536-544. [PubMed: 17272809]

3. Mangoni ME, Traboulsie A, Leoni AL, et al. Bradycardia and slowing of the atrioventricular conduction in mice lacking CaV3.1/alpha1G T-type calcium channels. Circ Res. 2006; 98(11): 1422-1430. [PubMed: 16690884]

4. Nuss HB, Houser SR. T-type Ca2+ current is expressed in hypertrophied adult feline left ventricular myocytes. Circ Res. 1993; 73(4):777-782. [PubMed: 8396509]

5. Martinez ML, Heredia MP, Delgado C. Expression of T-type $\mathrm{Ca}(2+)$ channels in ventricular cells from hypertrophied rat hearts. J Mol Cell Cardiol. 1999; 31(9):1617-1625. [PubMed: 10471346]

6. Xu XP, Best PM. Increase in T-type calcium current in atrial myocytes from adult rats with growth hormone-secreting tumors. Proc Natl Acad Sci U S A. 1990; 87(12):4655-4659. [PubMed: 2162052]

7. Sen L, Smith TW. T-type Ca2+ channels are abnormal in genetically determined cardiomyopathic hamster hearts. Circ Res. 1994; 75(1):149-155. [PubMed: 8013073]

8. Huang B, Qin D, Deng L, Boutjdir M, N E-S. Reexpression of T-type Ca2+ channel gene and current in post-infarction remodeled rat left ventricle. Cardiovasc Res. 2000; 46(3):442-449. [PubMed: 10912455]

9. Ferron L, Capuano V, Ruchon Y, Deroubaix E, Coulombe A, Renaud JF. Angiotensin II signaling pathways mediate expression of cardiac T-type calcium channels. Circ Res. 2003; 93(12):12411248. [PubMed: 14615287]

10. Chiang CS, Huang CH, Chieng H, Chang YT, Chang D, Chen JJ, Chen YC, Chen YH, Shin HS, Campbell KP, Chen CC. The $\mathrm{Ca}(\mathrm{v}) 3.2 \mathrm{~T}$-type $\mathrm{Ca}(2+)$ channel is required for pressure overloadinduced cardiac hypertrophy in mice. Circ Res. 2009; 104(4):522-530. [PubMed: 19122177]

11. Kinoshita H, Kuwahara K, Takano M, et al. T-type Ca2+ channel blockade prevents sudden death in mice with heart failure. Circulation. 2009; 120(9):743-752. [PubMed: 19687356]

12. Clozel JP, Ertel EA, Ertel SI. Voltage-gated T-type Ca2+ channels and heart failure. Proc Assoc Am Physicians. 1999; 111(5):429-437. [PubMed: 10519164]

J Cardiovasc Pharmacol. Author manuscript; available in PMC 2017 December 01. 
13. Jaleel N, Nakayama H, Chen X, Kubo H, MacDonnell S, Zhang H, Berretta R, Robbins J, Cribbs L, Molkentin JD, Houser SR. Ca2+ influx through T- and L-type Ca2+ channels have different effects on myocyte contractility and induce unique cardiac phenotypes. Circ Res. 2008; 103(10): 1109-1119. [PubMed: 18832749]

14. Le Quang K, Naud P, Qi XY, et al. Role of T-type calcium channel subunits in post-myocardial infarction remodelling probed with genetically engineered mice. Cardiovasc Res. 2011; 91(3):420428. [PubMed: 21622683]

15. Le Quang K, Benito B, Naud P, Qi XY, Shi YF, Tardif JC, Gillis MA, Dobrev D, Charpentier F, Nattel S. T-type calcium current contributes to escape automaticity and governs the occurrence of lethal arrhythmias after atrioventricular block in mice. Circ Arrhythm Electrophysiol. 2013; 6(4): 799-808. [PubMed: 23884198]

16. Nakayama H, Bodi I, Correll RN, Chen X, Lorenz J, Houser SR, Robbins J, Schwartz A, Molkentin JD. alpha1G-dependent T-type Ca2+ current antagonizes cardiac hypertrophy through a NOS3-dependent mechanism in mice. J Clin Invest. 2009; 119(12):3787-3796. [PubMed: 19920353]

17. David LS, Garcia E, Cain SM, Thau E, Tyson JR, Snutch TP. Splice-variant changes of the $\mathrm{Ca}(\mathrm{V}) 3.2 \mathrm{~T}$-type calcium channel mediate voltage-dependent facilitation and associate with cardiac hypertrophy and development. Channels (Austin, Tex.). 2010; 4(5):375-389.

18. Muth JN, Bodi I, Lewis W, Varadi G, Schwartz A. A Ca(2+)-dependent transgenic model of cardiac hypertrophy: A role for protein kinase Calpha. Circulation. 2001; 103(1):140-147. [PubMed: 11136699]

19. Molkentin JD, Lu JR, Antos CL, Markham B, Richardson J, Robbins J, Grant SR, Olson EN. A calcineurin-dependent transcriptional pathway for cardiac hypertrophy. Cell. 1998; 93(2):215-228. [PubMed: 9568714]

20. Rajan S, Ahmed RP, Jagatheesan G, Petrashevskaya N, Boivin GP, Urboniene D, Arteaga GM, Wolska BM, Solaro RJ, Liggett SB, Wieczorek DF. Dilated cardiomyopathy mutant tropomyosin mice develop cardiac dysfunction with significantly decreased fractional shortening and myofilament calcium sensitivity. Circ Res. 2007; 101(2):205-214. [PubMed: 17556658]

21. Alvarez JL, Salinas-Stefanon E, Orta G, Ferrer T, Talavera K, Galan L, Vassort G. Occurrence of a tetrodotoxin-sensitive calcium current in rat ventricular myocytes after long-term myocardial infarction. Cardiovasc Res. 2004; 63(4):653-661. [PubMed: 15306221]

22. Heubach JF, Kohler A, Wettwer E, Ravens U. T-Type and tetrodotoxin-sensitive $\mathrm{Ca}(2+)$ currents coexist in guinea pig ventricular myocytes and are both blocked by mibefradil. Circ Res. 2000; 86(6):628-635. [PubMed: 10746997]

23. Petrashevskaya NN, Bodi I, Rubio M, Molkentin JD, Schwartz A. Cardiac function and electrical remodeling of the calcineurin-overexpressed transgenic mouse. Cardiovasc Res. 2002; 54(1):117132. [PubMed: 12062368]

24. Leuranguer V, Monteil A, Bourinet E, Dayanithi G, Nargeot J. T-type calcium currents in rat cardiomyocytes during postnatal development: contribution to hormone secretion. Am J Physiol Heart Circ Physiol. 2000; 279(5):H2540-2548. [PubMed: 11045992]

25. Fuller-Bicer GA, Varadi G, Koch SE, et al. Targeted disruption of the voltage-dependent calcium channel alpha2/delta-1-subunit. Am J Physiol Heart Circ Physiol. 2009; 297(1):H117-124. [PubMed: 19429829]

26. Wilkins BJ, Dai YS, Bueno OF, Parsons SA, Xu J, Plank DM, Jones F, Kimball TR, Molkentin JD. Calcineurin/NFAT coupling participates in pathological, but not physiological, cardiac hypertrophy. Circ Res. 2004; 94(1):110-118. [PubMed: 14656927]

27. Nakayama H, Wilkin BJ, Bodi I, Molkentin JD. Calcineurin-dependent cardiomyopathy is activated by TRPC in the adult mouse heart. Faseb J. 2006; 20(10):1660-1670. [PubMed: 16873889]

28. Sanbe A, Gulick J, Hanks MC, Liang Q, Osinska H, Robbins J. Reengineering inducible cardiacspecific transgenesis with an attenuated myosin heavy chain promoter. Circ Res. 2003; 92(6):609616. [PubMed: 12623879] 
29. Cribbs LL, Martin BL, Schroder EA, Keller BB, Delisle BP, Satin J. Identification of the t-type calcium channel (Ca(v)3.1d) in developing mouse heart. Circ Res. 2001; 88(4):403-407. [PubMed: 11230107]

30. Bezprozvanny I, Tsien RW. Voltage-dependent blockade of diverse types of voltage-gated Ca2+ channels expressed in Xenopus oocytes by the Ca2+ channel antagonist mibefradil (Ro 40-5967). Mol Pharm. 1995; 48(3):540-549.

31. Lacinova L, Klugbauer N, Hofmann F. Regulation of the calcium channel alpha(1G) subunit by divalent cations and organic blockers. Neuropharmacology. 2000; 39(7):1254-1266. [PubMed: 10760367]

32. Szentandrassy N, Papp F, Hegyi B, Bartok A, Krasznai Z, Nanasi PP. Tetrodotoxin blocks native cardiac L-type calcium channels but not CaV1.2 channels expressed in HEK cells. J Physiol Pharmacol. 2013; 64(6):807-810. [PubMed: 24388896]

33. Aggarwal R, Shorofsky SR, Goldman L, Balke CW. Tetrodotoxin-blockable calcium currents in rat ventricular myocytes; a third type of cardiac cell sodium current. J Physiol. 1997; 505(Pt 2):353369. [PubMed: 9423179]

34. Cole WC, Chartier D, Martin M, Leblanc N. Ca2+ permeation through Na+ channels in guinea pig ventricular myocytes. Am J Physiol. 1997; 273(1 Pt 2):H128-137. [PubMed: 9249483]

35. Santana LF, Gomez AM, Lederer WJ. Ca2+ flux through promiscuous cardiac Na+ channels: slipmode conductance. Science. 1998; 279(5353):1027-1033. [PubMed: 9461434]

36. Sun H, Varela D, Chartier D, Ruben PC, Nattel S, Zamponi GW, Leblanc N. Differential interactions of $\mathrm{Na}+$ channel toxins with T-type Ca2+ channels. J Gen Physiol. 2008; 132(1):101113. [PubMed: 18591418]

37. Chorvatova A, Snowdon R, Hart G, Hussain M. Effects of pressure overload-induced hypertrophy on TTX-sensitive inward currents in guinea pig left ventricle. Mol Cell Biochem. 2004; 261(1-2): 217-226. [PubMed: 15362507]

38. Lemaire S, Piot C, Seguin J, Nargeot J, Richard S. Tetrodotoxin-sensitive Ca2+ and Ba2+ currents in human atrial cells. Receptors Channels. 1995; 3(2):71-81. [PubMed: 8581402]

39. Guatimosim S, Sobie EA, dos Santos Cruz J, Martin LA, Lederer WJ. Molecular identification of a TTX-sensitive Ca(2+) current. Am J Physiol. 2001; 280(5):C1327-1339.

40. Puglisi JL, Bers DM. LabHEART: an interactive computer model of rabbit ventricular myocyte ion channels and Ca transport. Am J Physiol. 2001; 281(6):C2049-2060.

41. Izumi T, Kihara Y, Sarai N, Yoneda T, Iwanaga Y, Inagaki K, Onozawa Y, Takenaka H, Kita T, Noma A. Reinduction of T-type calcium channels by endothelin-1 in failing hearts in vivo and in adult rat ventricular myocytes in vitro. Circulation. 2003; 108(20):2530-2535. [PubMed: 14581409]

42. Kuwahara K, Saito Y, Takano M, et al. NRSF regulates the fetal cardiac gene program and maintains normal cardiac structure and function. Embo J. 2003; 22(23):6310-6321. [PubMed: 14633990]

43. Vaidyanathan R, O'Connell RP, Deo M, Milstein ML, Furspan P, Herron TJ, Pandit SV, Musa H, Berenfeld O, Jalife J, Anumonwo JM. The ionic bases of the action potential in isolated mouse cardiac Purkinje cell. Heart Rhythm. 2013; 10(1):80-87. [PubMed: 23041576]

44. Houser $\mathrm{SR}$. $\mathrm{Ca}(2+)$ signaling domains responsible for cardiac hypertrophy and arrhythmias. Circ Res. 2009; 104(4):413-415. [PubMed: 19246682]

45. Koyama T, Ono K, Watanabe H, Ohba T, Murakami M, Iino K, Ito H. Molecular and electrical remodeling of $\mathrm{L}$ - and $\mathrm{T}$-type $\mathrm{Ca}(2+)$ channels in rat right atrium with monocrotaline-induced pulmonary hypertension. Circ J. 2009; 73(2):256-263. [PubMed: 19110506] 

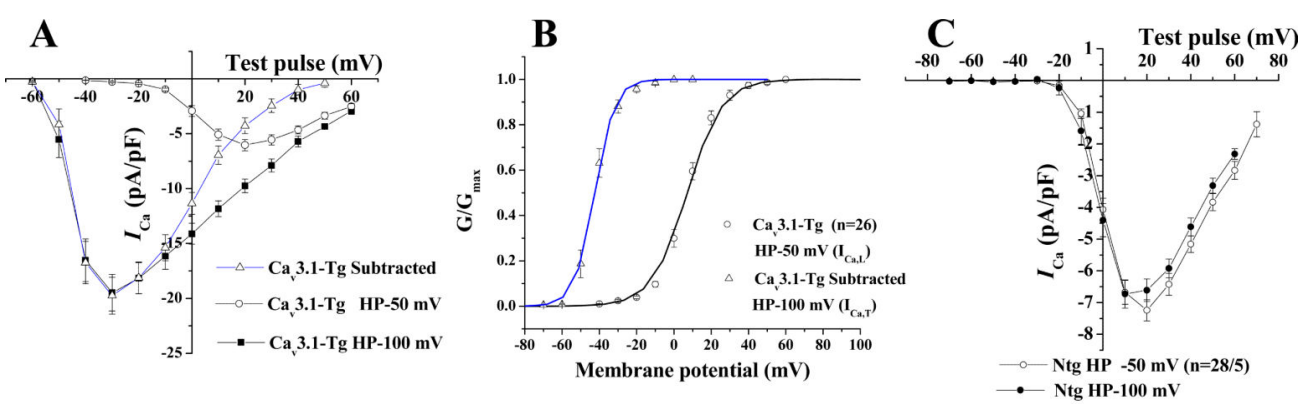

D

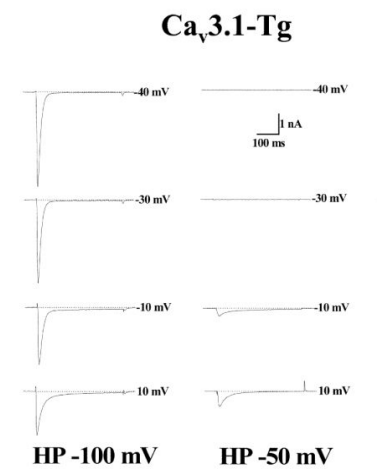

HP $-100 \mathrm{mV}$

HP -50 mV

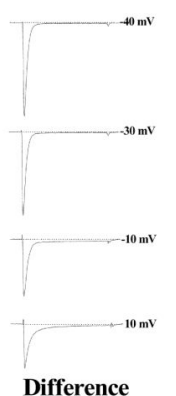

$\mathbf{E}$

Ntg
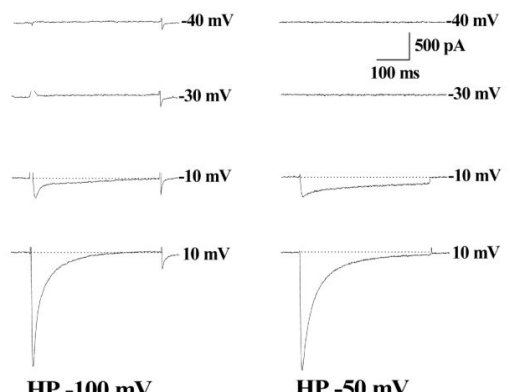

HP - $100 \mathrm{mV}$

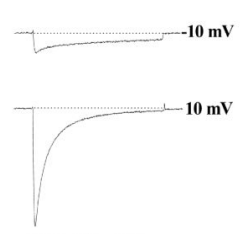

HP -50 mV

\section{F}
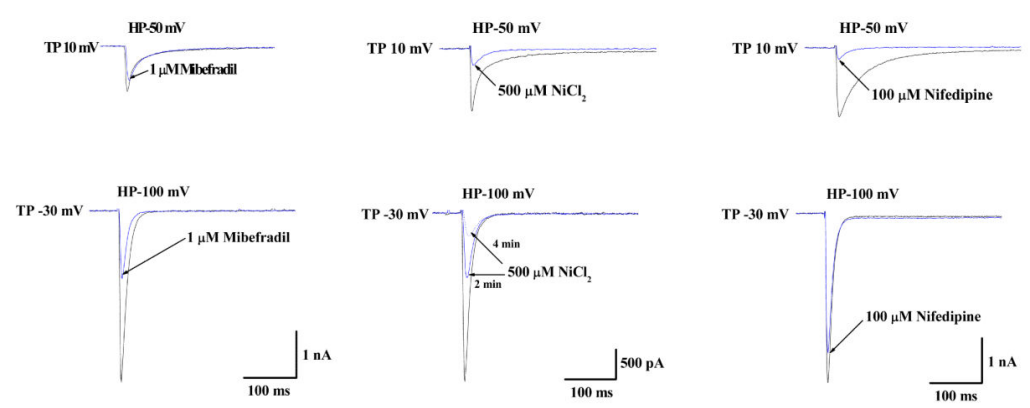

G

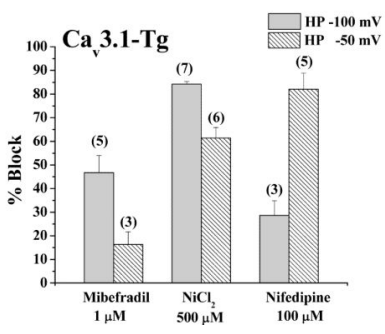

Figure 1.

$\mathrm{I}_{\mathrm{Ca}, \mathrm{L}}, \mathrm{I}_{\mathrm{Ca}, \text { total }}$ and $\mathrm{I}_{\mathrm{Ca}, \mathrm{T}}$ in $\mathrm{Ca}_{\mathrm{v}} 3.1-\mathrm{Tg}$ and Ntg ventricular myocytes (VM). (A) CurrentVoltage $(I-V)$ relationships. (B) Voltage dependence of activation from holding potential (HP) of $-100 \mathrm{mV}$ and $-50 \mathrm{mV}$; (C) $I-V$ relationships in Ntg (tTA) cardiomyocytes. (D) Typical $\mathrm{Ca}^{2+}$ currents recorded from VMs of $\mathrm{Ca}_{\mathrm{v}} 3.1-\mathrm{Tg}$ mice. Representative traces are shown for depolarizations to the indicated test potentials (TP) from HP of $-100 \mathrm{mV}$ (left) and $-50 \mathrm{mV}$ (middle); Right traces (Difference) show T-type current $\left(\mathrm{I}_{\mathrm{Ca}, \mathrm{T}}\right)$ obtained by subtracting currents elicited at the two HPs. The horizontal lines indicate the zero current 
levels. Using a HP of $-100 \mathrm{mV}$ depolarizing steps positive to $-60 \mathrm{mV}$ induced an inward maximal current at $-30 \mathrm{mV}$. At a $\mathrm{HP}$ of $-50 \mathrm{mV}$ the activation threshold was at $-30 \mathrm{mV}$. The difference between currents elicited from $\mathrm{HP}$ of $-100 \mathrm{mV}$ and $-50 \mathrm{mV}$ reveals the existence of $\mathrm{I}_{\mathrm{Ca}, \mathrm{T}}$ in $\mathrm{Ca}_{\mathrm{v}} 3.1-\mathrm{Tg}$ mice.

(E) Original current traces obtained with depolarizing voltage steps from HPs of $-100 \mathrm{mV}$ and $-50 \mathrm{mV}$ from VMs of Ntg (tTA)_ mice.

(F) Representative traces showing block of $\mathrm{I}_{\mathrm{Ca}}\left(\mathrm{Ca}_{\mathrm{v}} 3 \cdot 1-\mathrm{Tg}\right)$ before and after treatment of $1 \mu \mathrm{mol} / \mathrm{L}$ Mibefradil (Mib), $500 \mu \mathrm{mol} / \mathrm{L} \mathrm{NiCl}_{2}$ and $100 \mu \mathrm{mol} / \mathrm{L}$ Nifedipine (Nif). Figure shows superimposed current traces after stepping to $+10 \mathrm{mV}$ from the HP of $-50 \mathrm{mV}$ (upper panel) and lower panel shows current traces when stepping to $-30 \mathrm{mV}$ from HP of $-100 \mathrm{mV}$.

(G) Pharmacological properties of $\mathrm{I}_{\mathrm{Ca} \text {,total }}$ from $\mathrm{Ca}_{\mathrm{v}} 3.1-\mathrm{Tg}$ VMs. Histograms of the percentage of inhibition at $1 \mu \mathrm{mol} / \mathrm{L} \mathrm{Mib}(\mathrm{n}=5), 500 \mu \mathrm{mol} / \mathrm{L} \mathrm{Ni}^{2+}(\mathrm{n}=7)$ and $100 \mu \mathrm{mol} / \mathrm{l} \mathrm{Nif}$ $(\mathrm{n}=5)$ block of $\mathrm{I}_{\mathrm{Ca}}$ measured from a $\mathrm{HP}$ of $-100 \mathrm{mV}$ and $-50 \mathrm{mV}$, respectively as indicated. 
A

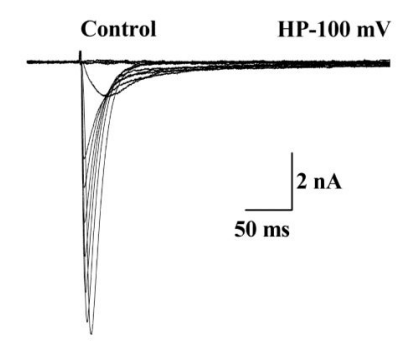

C

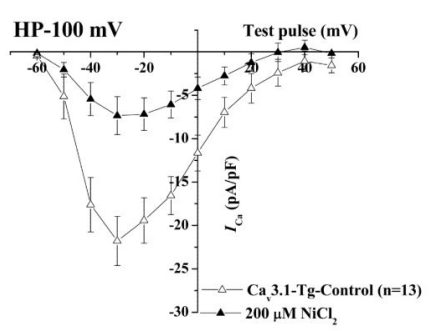

$\mathbf{E}$

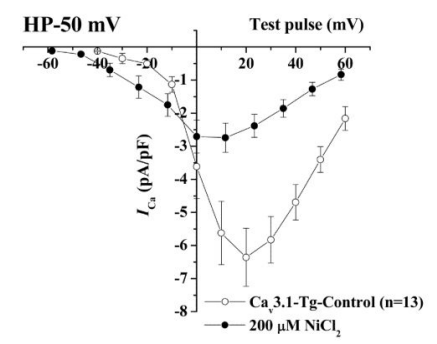

G

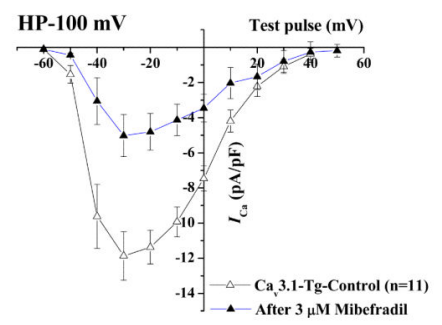

B

After $200 \mu \mathrm{M} \mathrm{NiCl}$
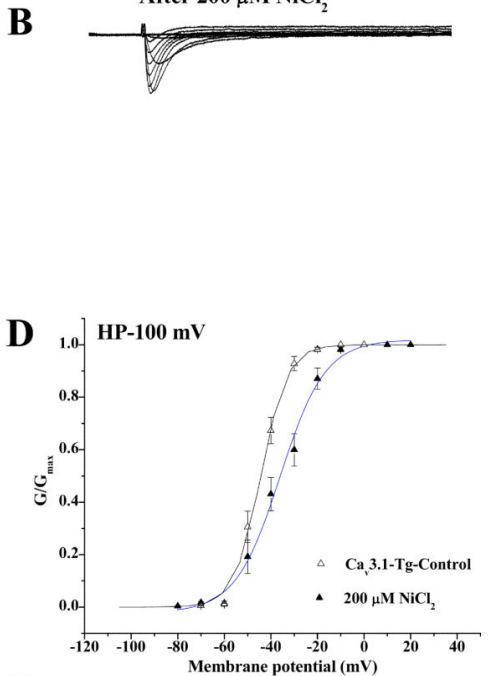

$\mathbf{F}$
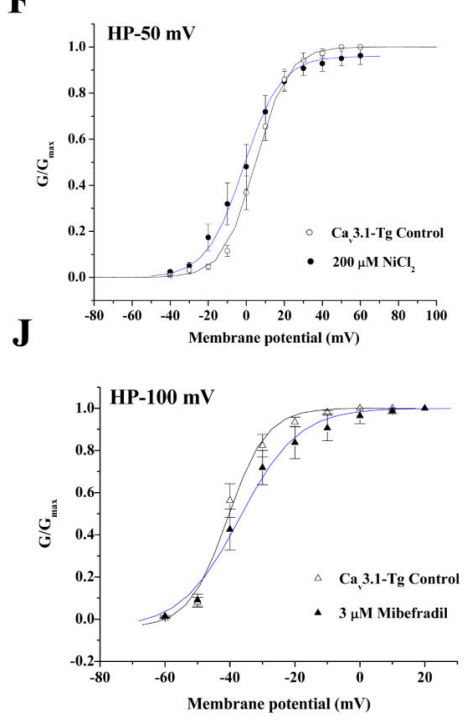

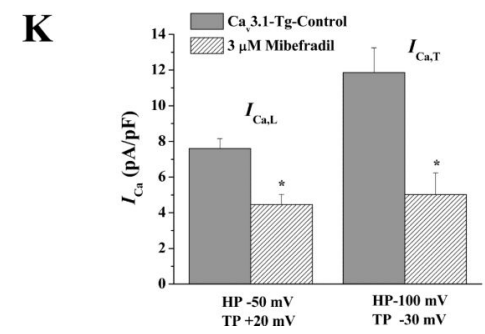

Figure 2.

Effect of $\mathrm{NiCl}_{2}$ and Mibefradil on voltage-dependent activation of $\mathrm{I}_{\mathrm{Ca}, \mathrm{T}}$ in cardiomyocytes obtained from $\mathrm{Ca}_{\mathrm{v}} 3.1-\mathrm{Tg}$ mice. $\mathrm{I}_{\mathrm{Ca} \text {,total }}$ recorded in Control (A) and in presence of $200 \mu \mathrm{mol} / 1 \mathrm{NiCl}_{2}$ (B). Current-voltage $(I-V)$ relation of the maximal $\mathrm{I}_{\mathrm{Ca}, \mathrm{T}}$ density vs. test potential (TP), for traces elicited from HP $-100 \mathrm{mV}\left(\mathrm{I}_{\mathrm{Ca}, \text { total }}\right)$ and $-50 \mathrm{mV}\left(\mathrm{I}_{\mathrm{Ca}, \mathrm{L}}, \mathrm{E}\right)$ and the subtracted current represented as $\mathrm{I}_{\mathrm{Ca}, \mathrm{T}}$ in absence and presence of $\mathrm{NiCl}_{2}(\mathrm{C})$. The voltagedependence of activation of $\mathrm{I}_{\mathrm{Ca}, \mathrm{T}}$ and $\mathrm{I}_{\mathrm{Ca}, \mathrm{L}}$ are presented in the absence (control) and in the presence of $200 \mu \mathrm{mol} / 1 \mathrm{NiCl}_{2}$ (D and F). $I-V$ relation of the maximal $\mathrm{I}_{\mathrm{Ca}, \mathrm{T}} \mathrm{vs}$. test potential, 
for traces elicited from $\mathrm{HP}-100 \mathrm{mV}\left(\mathrm{I}_{\mathrm{Ca}, \text { total }}\right)$ and $-50 \mathrm{mV}\left(\mathrm{I}_{\mathrm{Ca}, \mathrm{L}}\right)$ and the subtracted current represents $\mathrm{I}_{\mathrm{Ca}, \mathrm{T}}$ in absence and presence of $\mathrm{Mib}(\mathrm{G})$. The voltage-dependence of activation of $\mathrm{I}_{\mathrm{Ca}, \mathrm{T}}$ is illustrated in the absence (control) and in the presence of $3 \mu \mathrm{mol} / \mathrm{l} \mathrm{Mib} \mathrm{(J)}$ ). Bar graph representation of the peak $\mathrm{I}_{\mathrm{Ca}, \mathrm{T}}(\mathrm{HP}-100 \mathrm{mV})$ and $\mathrm{I}_{\mathrm{Ca}, \mathrm{L}}(\mathrm{HP}-50 \mathrm{mV})$ densities at $-30 \mathrm{mV}$ and $+20 \mathrm{mV}$, respectively, recorded in the absence and presence of $3 \mu \mathrm{mol} / \mathrm{l} \mathrm{Mib}(\mathrm{K})$. 

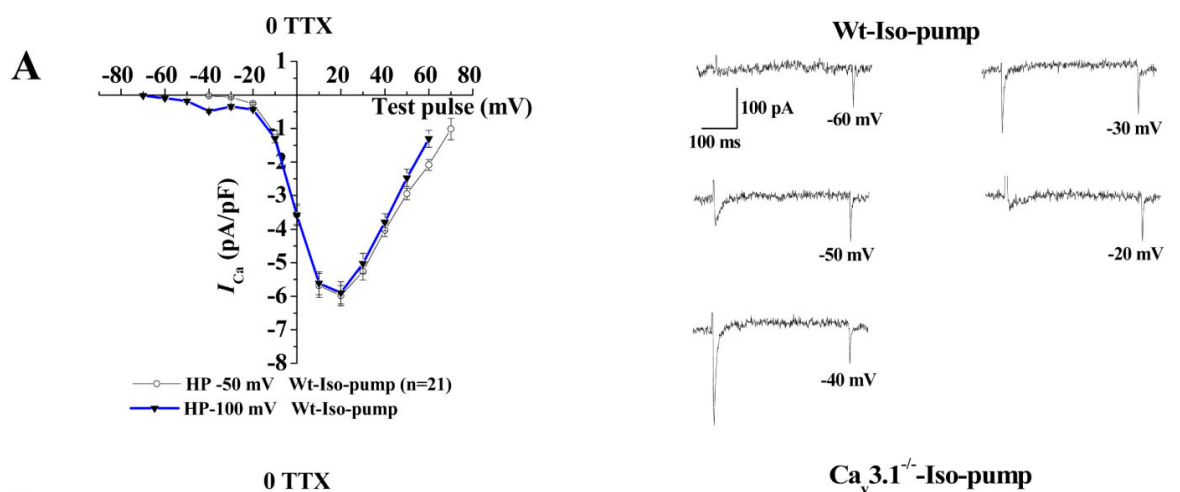

B
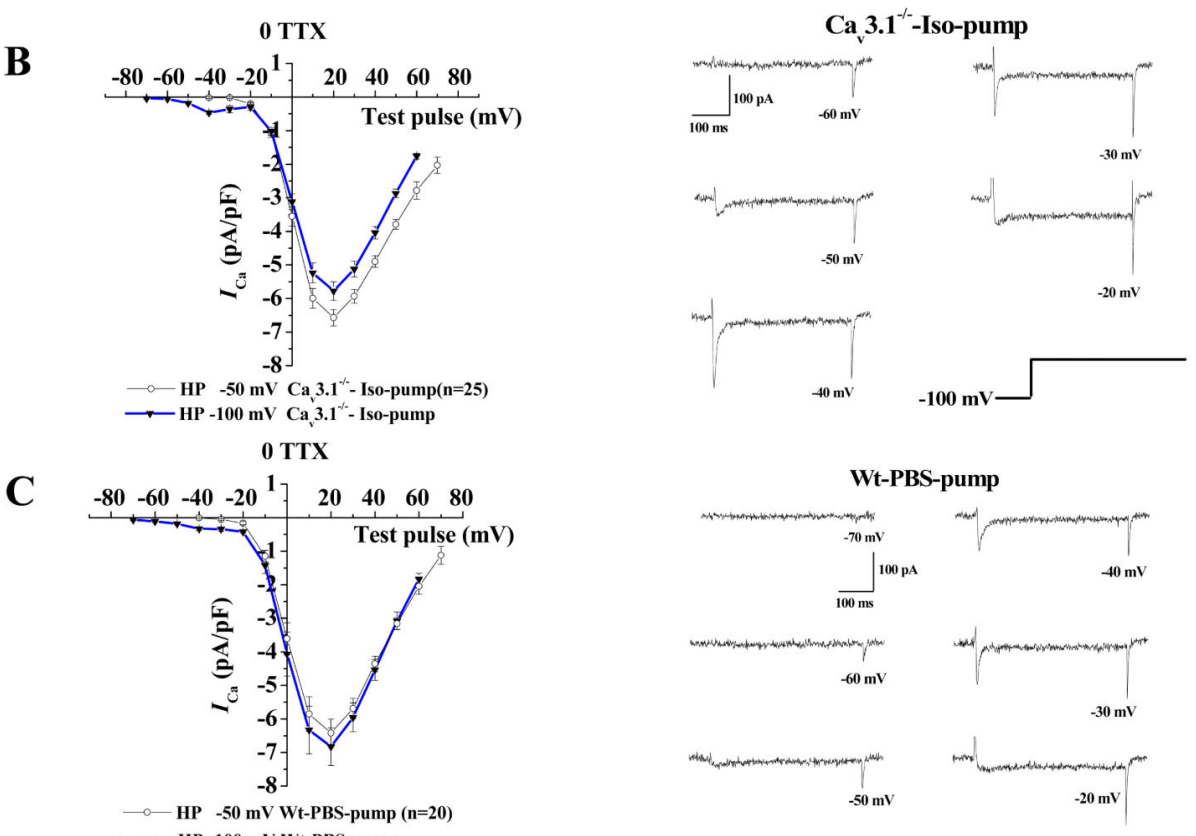

D

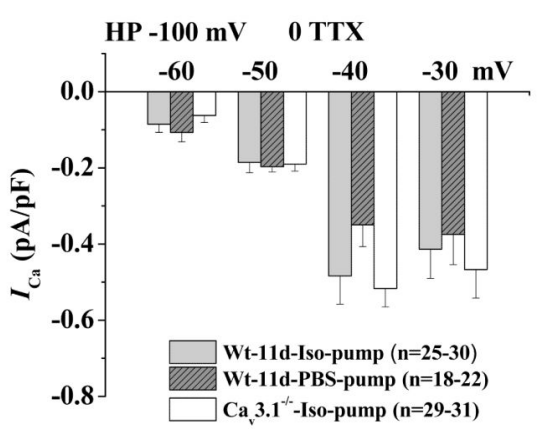

$\mathbf{E}$

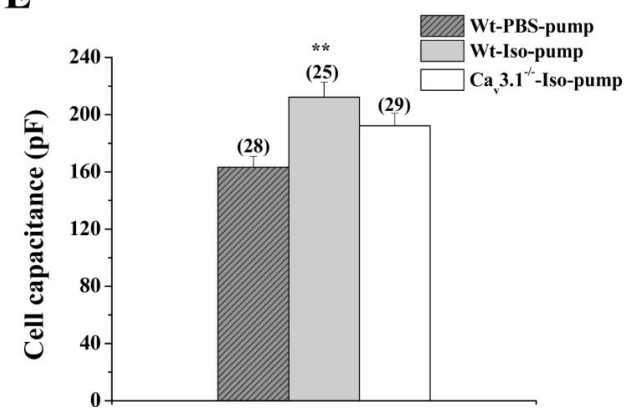

Figure 3.

Two types of inward current can be recorded when $\mathrm{Na}^{+}$is absent from the recording solution. Averaged current density-voltage relations of peak $\mathrm{I}_{\mathrm{Ca}}$ (left panels) in cardiomyocytes isolated from $\mathrm{Wt}(\mathrm{A}, \mathrm{n}=21 / 2)$ and $\mathrm{Ca}_{\mathrm{v}} 3 \cdot 1^{-/-}(\mathrm{B}, \mathrm{n}=28 / 4)$ mice after $\beta$ adrenergic stimulation (Iso) for 10-11 days. C, Wt-PBS $(n=20 / 2)$ treatment represents control condition. $\mathrm{I}_{\mathrm{Ca}}$ was elicited with a $380 \mathrm{~ms}$ depolarizing voltage steps from a HP of $-50 \mathrm{mV}$ and $-100 \mathrm{mV}$, to varying TPs, respectively. 
(A and B) (right panels): original LVA current recordings at indicated voltages in the absence of TTX, in Wt and $\mathrm{Ca}_{\mathrm{v}} 3 \cdot 1^{-/-}$cardiomyocytes treated for 10-11 days with Iso. (C) (right panel) presents currents recorded on voltage steps from $-70 \mathrm{mV}$ to $-20 \mathrm{mV}$ from a holding potential of $-100 \mathrm{mV}$ in Wt cardiomyocytes treated with PBS in absence of TTX. (D) Bar graph summarizing the peak LVA inward $\mathrm{I}_{\mathrm{Ca}}$ density at different TPs from $\mathrm{HP}$ of $-100 \mathrm{mV}$.

(E) Stress -induced cardiomyocyte hypertrophy was confirmed by the measurements of single cell capacitance $(\mathrm{pF})$, which was significantly larger in Wt-Iso pump compared with control (Wt-PBS pump). $\mathrm{Ca}_{\mathrm{v}} 3 \cdot 1^{-/-}$-Iso-pump mice showed the tendency to larger cell capacitance but fell short in significance.

$* * \mathrm{p}<0.001, * \mathrm{p}<0.05$ vs Wt PBS-pump. 
A

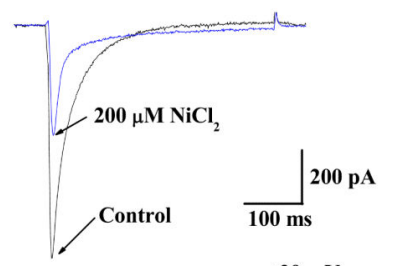
$\mathrm{HP}-50 \mathrm{mV}$

B

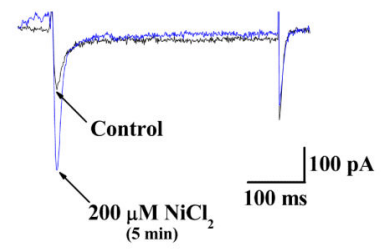
$\mathrm{HP}-100 \mathrm{mv}$

C

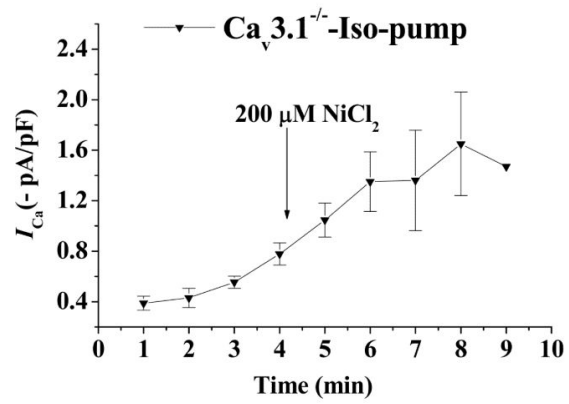

$\mathbf{E}$

Ca $_{v} 3.1^{-1-\text {-Iso-pump }}$
$\mathrm{Ca}_{v}$ 3.1 ${ }^{-1-\text { Iso-pump }}$
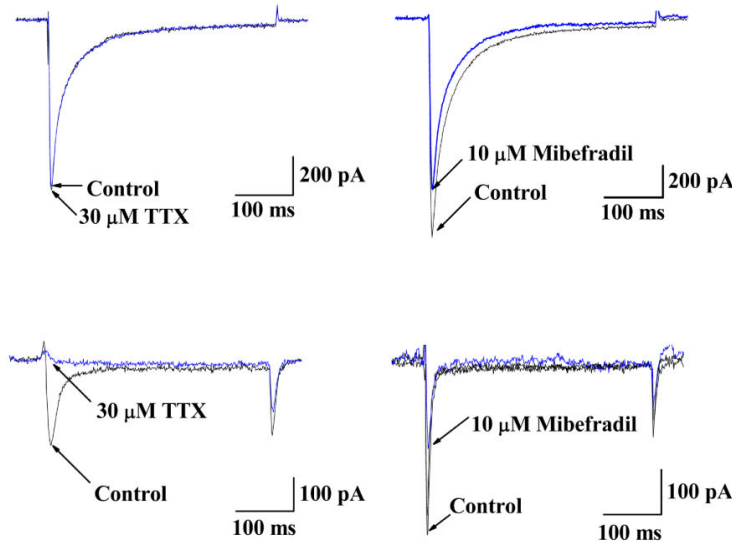
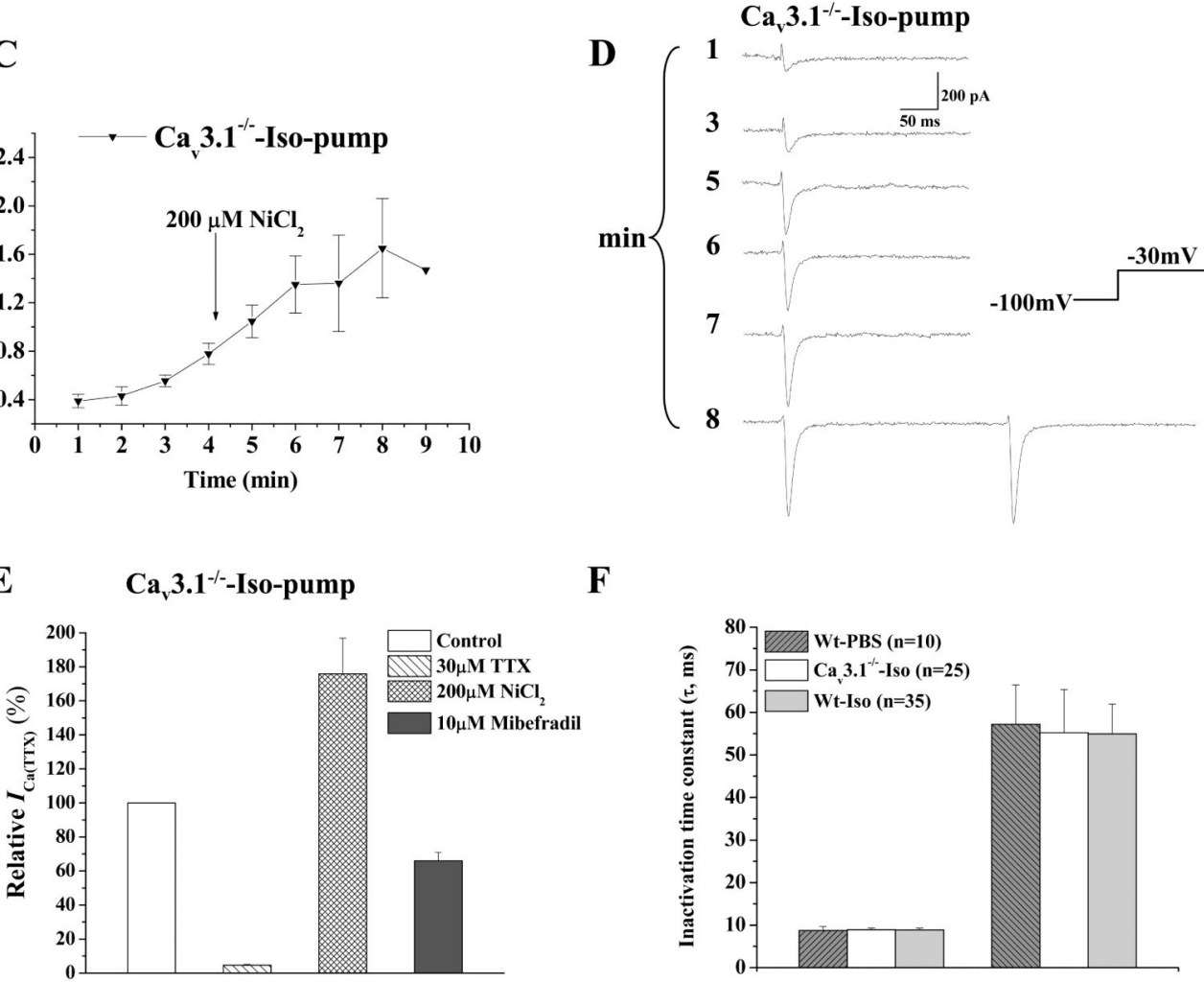

$\mathbf{F}$

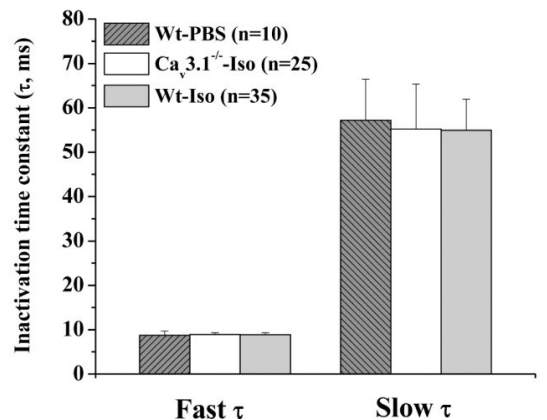

Figure 4.

Pharmacological and biophysical characterization of LVA inward $\mathrm{Ca}^{2+}$ current.

Superimposed original $\mathrm{I}_{\mathrm{Ca}}$ traces in cardiomyocytes elicited by step depolarization from HP of $-50 \mathrm{mV}(\mathrm{A})$ and $-100 \mathrm{mV}$ (B) to the indicated voltages before and after application of $\mathrm{NiCl}_{2}$ (left panel), TTX (middle panel) and Mib (right panel).

(C) Time-dependent effect of $200 \mu \mathrm{mol} / \mathrm{L} \mathrm{NiCl} 2$ on averaged LVA peak current densities at $-30 \mathrm{mV}$ from $\mathrm{HP}$ of $-100 \mathrm{mV}$ in cardiomyocytes $(\mathrm{n}=5)$ derived from $\mathrm{Ca}_{\mathrm{v}} 3.1^{-/-}$mice. (D) Effects of repetitive depolarization on $\mathrm{LVA} \mathrm{Ca}{ }^{2+}$ current. Representative LVA Ca ${ }^{2+}$ current 
traces were obtained from a cell repetitively depolarized from $\mathrm{HP}$ of $-100 \mathrm{mV}$ to $-30 \mathrm{mV}$ in recording solution containing $2 \mathrm{mmol} / \mathrm{L} \mathrm{Ca}^{2+}$. Traces are time courses of changes in LVA peak current during control measurements (for $8 \mathrm{~min}$ ).

(E) Bar graph summarizing the effects of the various compounds for experiments similar to those illustrated in (A) and (B). As in (A), each compound was tested in different cells at two different holding potentials (HP) as indicated. Each column represents the mean \pm SEM $\%$ blockade relative to the control value (open bar) of $\mathrm{I} \mathrm{by} \mathrm{Ni}^{2+}$, Mib and TTX. LVA $\mathrm{I}_{\mathrm{Ca}(\mathrm{TTX})}$ current was inhibited $95.4 \%$ by $30 \mu \mathrm{mol} / \mathrm{L}$ TTX (Control: $0.45 \pm 0.06 \mathrm{pA} / \mathrm{pF}$, TTX: $0.004 \pm 0.001 \mathrm{pA} / \mathrm{pF}, \mathrm{n}=7$ ) and $34.1 \%$ by $20 \mu \mathrm{mol} / \mathrm{L}$ Mib (Control: $2.48 \pm 0.15 \mathrm{pA} / \mathrm{pF}$, Mib: $1.64 \pm 0.18 \mathrm{pA} / \mathrm{pF}, \mathrm{n}=5$ ), but it was insensitive for $200 \mu \mathrm{mol} / \mathrm{L} \mathrm{Ni}^{2+}$. The changes reflect the "run-up" which is characteristic of the TTX-sensitive $\mathrm{I}_{\mathrm{Ca}}$ (Control: $0.78 \pm 0.088 \mathrm{pA} / \mathrm{pF}$, after application of $\mathrm{Ni}^{2+}: 3 \mathrm{~min}$ and $4 \mathrm{~min} 1.36 \pm 0.39 \mathrm{pA} / \mathrm{pF}$ and $1.65 \pm 0.41 \mathrm{pA} / \mathrm{pF}$, respectively, $\mathrm{n}=5$ ).

(F) Inactivation kinetics of $\mathrm{I}_{\mathrm{Ca}(\mathrm{TTX})}$ observed in $\mathrm{Wt}$ and $\mathrm{Ca}_{\mathrm{v}}{ }^{-1-}$ cardiomyocytes after chronic treatment with Iso or PBS.

The LVA inward $\mathrm{I}_{\mathrm{Ca}}$ was elicited by $380 \mathrm{~ms}$ steps to $-30 \mathrm{mV}$ from a HP of $-100 \mathrm{mV}$. Bar graph representing the fast $\left(\tau_{\text {fast }}\right)$ and slow $\left(\tau_{\text {slow }}\right)$ time constants of inactivation. There were no significant differences between the groups. 
$\mathbf{A}$

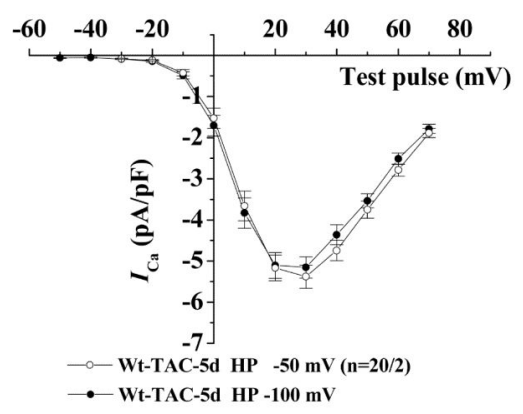

C

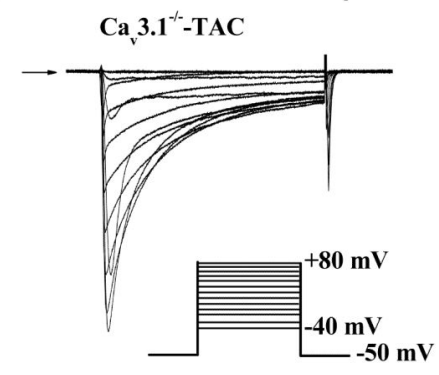

$\longrightarrow$ Wt-TAC-5d HP $\quad-50 \mathrm{mV}(\mathrm{n}=20 / 2)$
$\longrightarrow$ Wt-TAC-5d HP $-100 \mathrm{mV}$
$30 \mu \mathrm{M}$ TTX

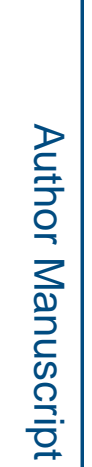

B

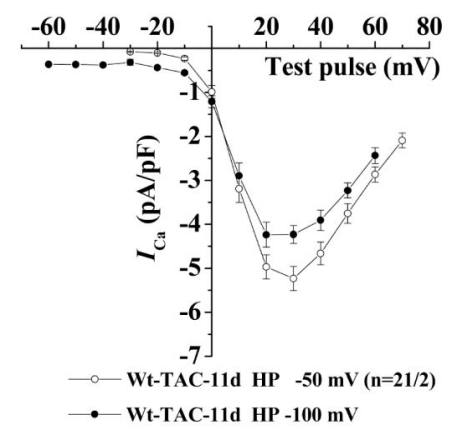

D

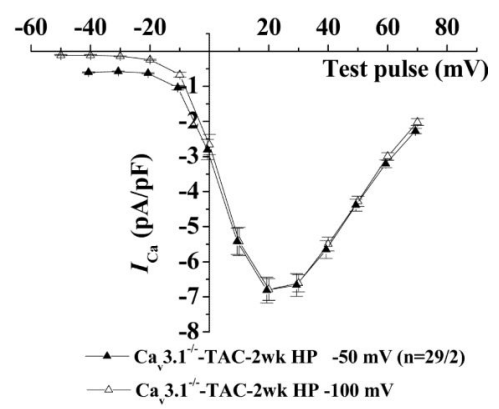

$\mathbf{E}$

$\mathrm{Ca}_{\mathrm{v}} 3.1^{-1-}$-TAC

$\mathbf{F}$

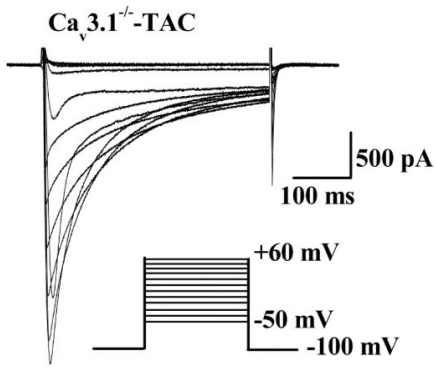

$-100 \mathrm{mV}$

0 TTX
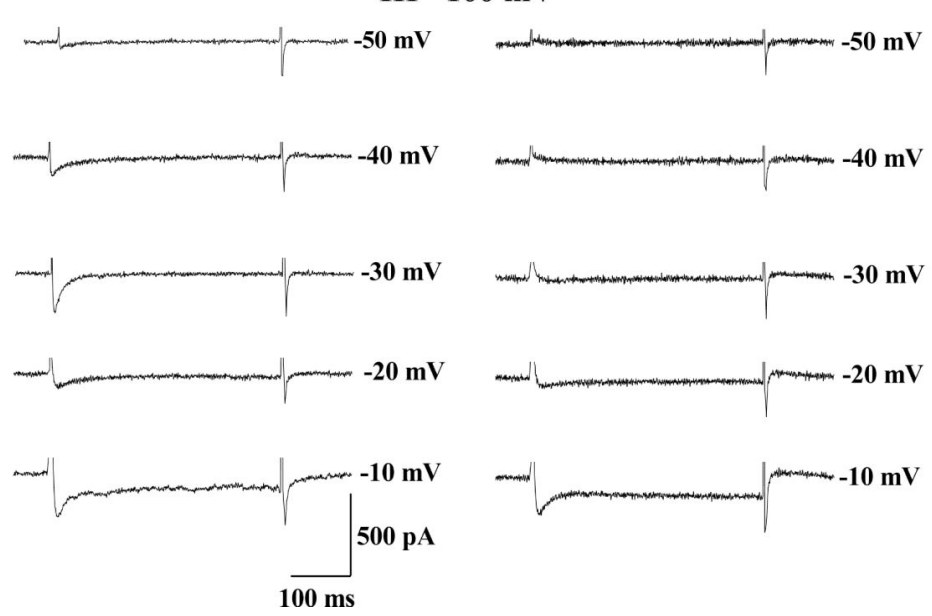
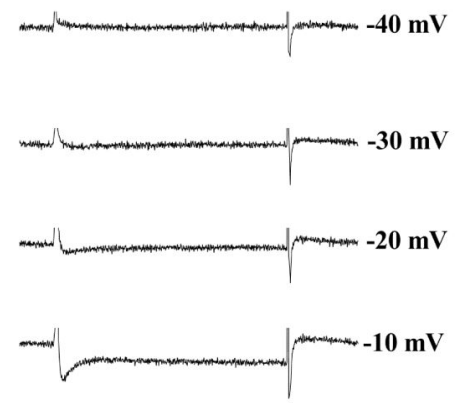
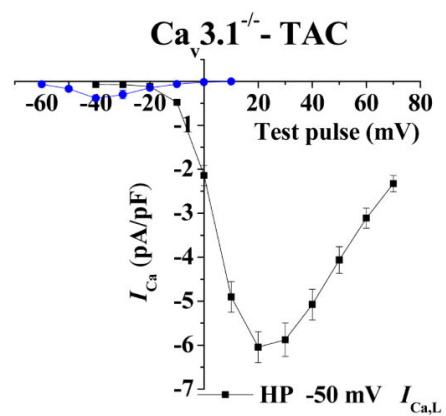

- HP-100 mV $I_{\mathrm{Ca}(\mathrm{TTX})}$

Figure 5.

Effects of pressure overload on $\mathrm{I}_{\mathrm{Ca}}$ in cardiomyocytes from $\mathrm{Wt}$ and $\mathrm{Ca}_{\mathrm{v}} 3.1^{-/-}$mice.

(A) Average, superimposed $I-V$ relationships of $\mathrm{I}_{\mathrm{Ca}}$ in Wt ventricular cardiomyocytes (VM) after 5 days (d) and (B) 11 days of TAC in the presence of $30 \mu \mathrm{mol} / \mathrm{L}$ TTX from HP of $-50 \mathrm{mV}$ and $-100 \mathrm{mV}$, respectively.

(C) Families of current traces obtained from $\mathrm{Ca}_{\mathrm{v}} 3 \cdot 1^{-/-}$VMs subjected to TAC for 2 weeks (wk) at $\mathrm{HP}$ of $-50 \mathrm{mV}$ (left panel) and $-100 \mathrm{mV}$ (right panel) in presence of $30 \mu \mathrm{mol} / \mathrm{L}$ TTX. 
Representative current traces recorded during steps to indicated voltages in VMs by the voltage clamp protocol shown in the inset at the bottom.

(D) Mean $\pm \mathrm{SEM}$, superimposed $I-V$ curves of $\mathrm{I}_{\mathrm{Ca}, \mathrm{L}}$ and $\mathrm{I}_{\mathrm{Ca} \text {,total }}$ in the presence of TTX. (E) Typical LVA Ca ${ }^{2+}$ currents from $\mathrm{Ca}_{\mathrm{v}} 3 \cdot 1^{-/-} \mathrm{VMs}$ derived from mice subjected to TAC for 2 weeks. Representative traces are shown for step depolarization's to the indicated test potentials (TPs) from HP of $-100 \mathrm{mV}$ in the absence (left panel) and in the presence (right

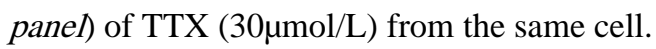

(F) $I-V$ relationship of $\mathrm{I}_{\mathrm{Ca}(\mathrm{TTX})}$ and $\mathrm{I}_{\mathrm{Ca}, \mathrm{L}}$ currents in $\mathrm{Ca}_{\mathrm{v}} 3.1^{-/-}$VMs subjected to TAC for 2 weeks in the absence of TTX. 
A

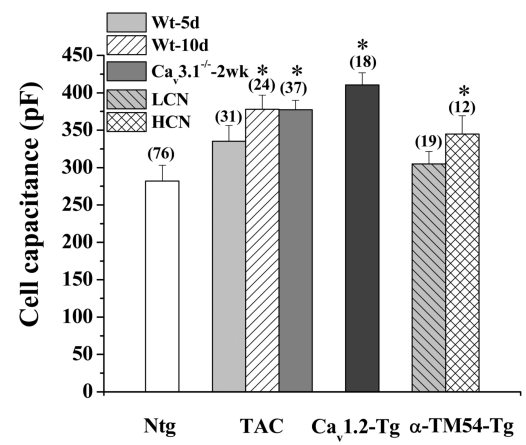

B

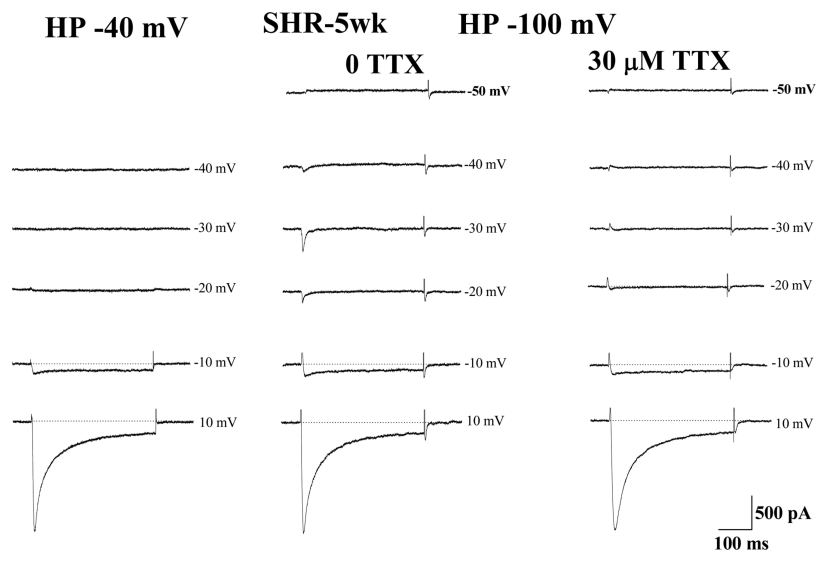

C

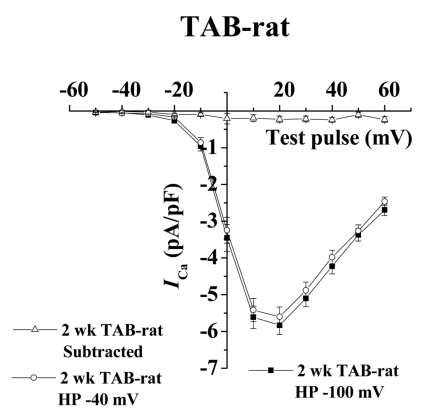

D

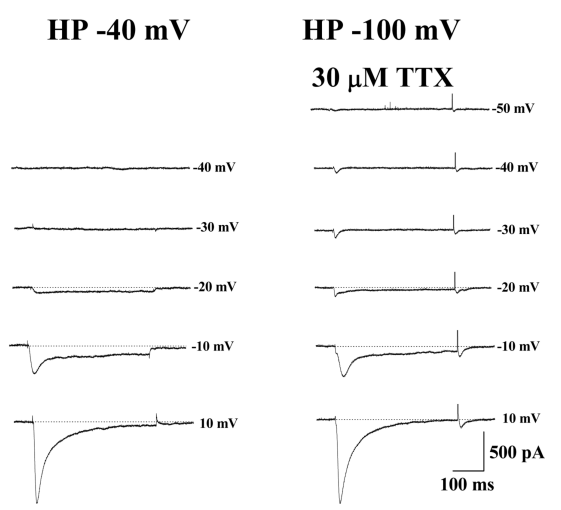

Figure 6.

(A) Comparision of cell capacitance $(\mathrm{pF})$ in cardiomyocytes from different hypertrophic models. *p $<0.05$ vs Ntg

LCN=Low copy number

$\mathrm{HCN}=$ High copy number

(B) Representative traces of $\mathrm{I}_{\mathrm{Ca}}$ elicited by $400 \mathrm{~ms}$ depolarizing test pulses to the indicated voltages from holding potentials (HPs) of $-40 \mathrm{mV}$ (left panel) and $-100 \mathrm{mV}$ in ventricular cell derived from 5 weeks (wk) old SHR in the absence (middle) and in the presence of TTX 
(right panel). Appearance of $\mathrm{I}_{\mathrm{Ca}(\mathrm{TTX})}$ was abolished by $30 \mu \mathrm{mol} / \mathrm{L}$ TTX in the recording solution (right panel).

(C) $I$ - $V$ relations of $\mathrm{I}_{\mathrm{Ca}}$ determined at the HPs of $-100 \mathrm{mV}\left(\mathrm{I}_{\mathrm{Ca} \text {,total }}\right)$ and $-40 \mathrm{mV}\left(\mathrm{I}_{\mathrm{Ca}, \mathrm{L}}\right)$ in cardiomyocytes derived from $2 \mathrm{wk}$ TAC-operated rat heart.

$\mathrm{T}$-type $\mathrm{Ca}^{2+}$ current reappearance in $\mathrm{Wt}$ rat ventricular myocyte after thoracic aortic constriction. (D) Representative current recordings of $\mathrm{I}_{\mathrm{Ca}, \mathrm{L}}$ and $\mathrm{I}_{\mathrm{Ca}, \mathrm{T}}$ are shown at $\mathrm{HP}$ of $-40 \mathrm{mV}$ (left panel) and $-100 \mathrm{mV}$ (right panel; 30 $\mathrm{mol} / \mathrm{L}$ TTX was included in the recording solution), respectively. Zero current level is indicated by the dotted line. 